OPEN ACCESS

Edited by:

Diego Sanchez,

University of Valladolid, Spain

Reviewed by:

Aleksandra Klisic,

Primary Health Care Center

Podgorica, Montenegro

loannis Papassotiriou,

Agia Sophia Children's Hospital,

Greece

${ }^{*}$ Correspondence:

Julia S. Steinhoff

julia.steinhoff@charite.de

Michael Schupp

michael.schupp@charite.de

Specialty section:

This article was submitted to

Integrative Physiology,

a section of the journal

Frontiers in Physiology

Received: 28 January 2021

Accepted: 22 February 2021

Published: 11 March 2021

Citation:

Steinhoff JS, Lass A and Schupp M (2021) Biological Functions of RBP4 and Its Relevance for Human Diseases. Front. Physiol. 12:659977. doi: 10.3389/fphys.2021.659977

\section{Biological Functions of RBP4 and Its Relevance for Human Diseases}

\author{
Julia S. Steinhoff ${ }^{*}$, Achim Lass ${ }^{2,3}$ and Michael Schupp ${ }^{1 *}$ \\ ${ }^{1}$ Institute of Pharmacology, Charité-Universitätsmedizin Berlin, Corporate Member of Freie Universität Berlin, \\ Humboldt-Universität zu Berlin, and Berlin Institute of Health, Berlin, Germany, ${ }^{2}$ Institute of Molecular Biosciences, NAWI \\ Graz, University of Graz, Graz, Austria, ${ }^{3}$ BioTechMed-Graz, Graz, Austria
}

Retinol binding protein 4 (RBP4) is a member of the lipocalin family and the major transport protein of the hydrophobic molecule retinol, also known as vitamin $\mathrm{A}$, in the circulation. Expression of RBP4 is highest in the liver, where most of the body's vitamin A reserves are stored as retinyl esters. For the mobilization of vitamin A from the liver, retinyl esters are hydrolyzed to retinol, which then binds to RBP4 in the hepatocyte. After associating with transthyretin (TTR), the retinol/RBP4/TTR complex is released into the bloodstream and delivers retinol to tissues via binding to specific membrane receptors. So far, two distinct RBP4 receptors have been identified that mediate the uptake of retinol across the cell membrane and, under specific conditions, bi-directional retinol transport. Although most of RBP4's actions depend on its role in retinoid homeostasis, functions independent of retinol transport have been described. In this review, we summarize and discuss the recent findings on the structure, regulation, and functions of RBP4 and lay out the biological relevance of this lipocalin for human diseases.

Keywords: RBP4, retinol transport, liver, retinoids, vitamin A, lipocalin, metabolism

\section{GENERAL INTRODUCTION}

Vitamin A, which comprises retinol and its biologically relevant metabolites, belongs to the group of fat-soluble vitamins and is essential for humans (McCollum and Davis, 1913). It is famously involved in the physiology of vision, but moreover, it is also known to play roles in immune cell function, reproduction, embryonic development, and the regulation of cell proliferation and differentiation (Morriss-Kay and Sokolova, 1996; Napoli, 1996; Blaner et al., 1999; Blaner, 2007).

Most of vitamin A's actions are mediated by its active metabolite all-trans retinoic acid (atRA) acting as the high affinity agonist ligand for the three known isoforms of retinoic acid receptors (RAR) $\alpha, \beta$, and $\gamma$ (Petkovich et al., 1987). A 9-cis configurated RA derivative, whose exact nature and physiological context is still under investigation, activates retinoid X receptors (RXR) (Heyman et al., 1992; Levin et al., 1992; Rühl et al., 2015). Both RAR and RXR belong to the family of nuclear receptors that serve as ligand-activated transcription factors. In contrast to regulating gene expression, 11-cis retinaldehyde in the eye is the light-sensitive chromophore of the rhodopsin complex to allow for the visual cycle in the retina (Palczewski et al., 2000). A deficit of vitamin A and as a consequence 11-cis retinaldehyde is evident by impaired vision, leading to night blindness or even full blindness (Blegvad, 1924). Vitamin A deficiency due to malnutrition during pregnancy is the leading cause for visual defects in newborns in developing countries (Pirie, 1983). Thus, vitamin $\mathrm{A}$ is required for both development (RA- and nuclear receptor-mediated) and functionality (11-cis 
retinaldehyde-mediated) of the eye, underlining its extraordinary dependence on vitamin A.

Lipocalins are a family of proteins with the ability to bind and transport small lipophilic proteins (Pervaiz and Brew, 1987). A prominent member of this family is retinol binding protein 4 (RBP4, also known as RBP) (Kanai et al., 1968; Quadro et al., 1999), which is central to this review. As suggested by its name, RBP4 transports retinol and is considered the only specific binding protein in the circulation (Kanai et al., 1968). As such and most likely also via non-canonical functions, RBP4 is implicated in a variety of human conditions that include impaired vision and ocular diseases (Li et al., 2010), disorders of glucose and lipid homeostasis (Yang et al., 2005), and cardiovascular diseases (Sun et al., 2013). This review will summarize the current knowledge of the biological functions of RBP4 and how the lipocalin is linked to these pathologies.

\section{DISCOVERY AND PROTEIN STRUCTURE OF RBP4}

In 1968 Kanai et al. were first to describe RBP4 as a human plasma protein that is bound specifically to retinol and functioning as its transporter in the circulation. In their study, they analyzed plasma of subjects that had been injected intravenously with radio-labeled retinol. They were able to purify the protein that had bound labeled retinol and named it RBP (Kanai et al., 1968). Besides binding retinol, they found it to be circulating in complex with another, larger protein with prealbumin mobility on electrophoresis. Since then, there have been numerous studies on the biology of RBP4, dissecting its structure, function, and its role in the context of human diseases.

The primary structure of the $21 \mathrm{kDa}$ protein was characterized as a single polypeptide chain, containing 201 amino acids and three disulfide bridges in humans (Rask et al., 1980, 1987). An N-terminal secretory signal peptide of 18 amino acid is cleaved upon protein processing. The complete $3 \mathrm{D}$ structure of RBP4 was reported by Newcomer et al. (1984). Using x-ray crystallography, they found that its structure is built not only of an $\mathrm{N}$-terminal coil, a C-terminal $\alpha$-helix followed by a coil region, but also a characteristic $\beta$-barrel core that they described as an eight-stranded up-and-down $\beta$-barrel. This $\beta$-barrel core is the structural part of the RBP4 molecule that is able to specifically host one molecule of retinol, which keeps this hydrophobic vitamin soluble in an aqueous milieu, and therefore capable of transporting it through the bloodstream.

\section{TRANSCRIPTIONAL AND POST-TRANSLATIONAL REGULATION OF RBP4}

RBP4 is highest expressed in the liver followed by robust expression in all adipose tissue depots (Tsutsumi et al., 1992; Wu C. et al., 2009, 2013). Nevertheless, its mRNA can be detected in several other tissues and anatomical structures, such as kidney, retinal pigment epithelium, testes, brain, lung, and the choroid plexus (Soprano et al., 1986; Blaner, 1989; MacDonald et al., 1990; Duan and Schreiber, 1992; Soprano and Blaner, 1994; O’Byrne and Blaner, 2013). Highest expression in liver coincides with the highest retinoid stores of any organ, corresponding to about $80 \%$ of all retinoids in the body (O'Byrne and Blaner, 2013).

Several genomic elements in the 5' flanking region of the human RBP4 gene confer its high expression in hepatocytes, although the occupancy with specific transcriptional regulators has not been characterized thoroughly (D'Onofrio et al., 1985; Colantuoni et al., 1987; Blaner, 1989). However, a multiprotein complex including high mobility group A1, protein-associated splicing factor, steroidogenic factor 1 , and other proteins was shown to be recruited to its promoter, especially upon stimulation by cyclic AMP (Bianconcini et al., 2009; Chiefari et al., 2009), a known inducer of $R b p 4$ mRNA expression in murine hepatocytes (Jessen and Satre, 1998). In mice, liver Rbp4 mRNA is elevated by injecting glucagon (Bianconcini et al., 2009). Consistently, Rbp4 mRNA expression in liver is induced by fasting. Interestingly, this fasting induction was also observed in mice that lack peroxisome proliferator-activated receptor $\alpha(\operatorname{PPAR} \alpha)($ Smati et al., 2020), the master regulator of the transcriptional response to fasting in liver (Kersten et al., 1999), which is in accordance with a cAMP-dependent and PPAR $\alpha$ independent mechanism.

Rats with either normal, retinol-depleted, or retinol-repleted status did not show any alterations in the expression or synthesis of $R b p 4$ mRNA and protein in liver, respectively (Soprano et al., 1982), suggesting that hepatic gene expression of $R b p 4$ is independent of the overall vitamin A status. On the other hand, both atRA and 9-cis RA induced Rbp4 mRNA expression in murine Hepa 1-6 cells and in mouse liver in vivo in a doseand time-dependent manner (Jessen and Satre, 2000), showing that at least at higher concentrations, these retinoids are able to induce $R b p 4$ mRNA. Another study showed that atRA treatment of mice reduced mRNA expression of $R b p 4$ in adipose tissues but not liver, whereas protein levels of RBP4 were reduced in liver and increased in serum (Mercader et al., 2008).

Very little is known about the translational control of $R b p 4$ mRNA. Welles et al. showed that in response to re-feeding of fasted mice, translation of Rbp4 mRNA in liver was enhanced, most likely in a 'mechanistic target of rapamycin in complex 1' (mTORC1)-dependent manner. In support of this was the finding that rapamycin, an inhibitor of mTORC1, prevented the nutrientinduced translation of Rbp4 mRNA (Welles et al., 2020). Major regulators of $R b p 4$ transcription and translation are depicted in Figure 1.

In humans, RBP4 circulates as the native full-length protein of 183 amino acids. Interestingly, in patients with chronic renal failure, two additional forms of RBP were identified, lacking one or both of the C-terminal amino acids leucine (Jaconi et al., 1995). The authors suggested that these C-terminally truncated RBP4 proteins are generated in hepatocytes and, after its release, are rapidly cleared by the kidney in healthy individuals, but not in patients with chronic renal failure (Jaconi et al., 1995). Moreover, chronic diseases of the kidney but not of the liver in human patients associated with higher levels of truncated proteins in the circulation (Frey et al., 2008). The physiologic role of these 


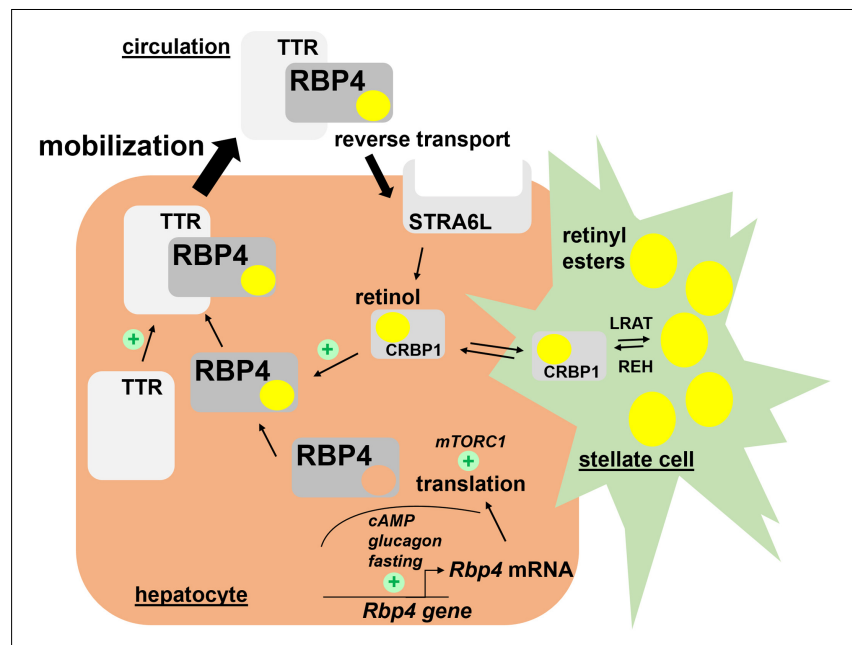

FIGURE 1 | Hepatic retinol mobilization by RBP4. Most of liver retinoids are stored as retinyl esters in hepatic stellate cells in a LRAT-dependent manner. Upon hydrolysis by REH, retinol binds CRBP1 and becomes available to associate with RBP4 in hepatocytes. After complex formation with TTR, retinol/RBP4/TTR is secreted into the circulation. Both steps enhance secretion of the complex since depletion of retinol or TTR induces RBP4 accumulation in hepatocytes. Hepatocyte-expressed STRA6L is thought to confer reverse retinol transport from circulating holo-RBP4. Expression of Rbp4 mRNA is induced by cAMP/glucagon signaling and RBP4 protein translation enhanced by mTORC1 activation. Please note that pathways for uptake and storage of dietary retinoids from circulating lipoproteins, which are thought to be RBP4-independent, are not included in the figure. CAMP, cyclic adenosine monophosphate; CRBP1, cellular retinol binding protein 1; LRAT, lecithin retinol acyltransferase; mTORC1, mechanistic target of rapamycin in complex 1; RBP4, retinol binding protein 4; REH, retinyl ester hydrolases; STRA6L, stimulated by retinoic acid 6-like; TTR, transthyretin.

truncated RBP4 proteins, which are still able to bind retinol (Jaconi et al., 1996), is currently unknown.

\section{TISSUE-SPECIFIC CONTRIBUTIONS TO CIRCULATING RBP4}

The concentration of RBP4 in blood, and therefore also retinol, is rather tightly regulated and kept normally at about $2-3 \mu \mathrm{M}$ in humans and around $1 \mu \mathrm{M}$ in mice, despite changes in the daily uptake of retinoids with the diet (Shirakami et al., 2012). Since RBP4 is expressed in many tissues and cell types, the specific contribution of each of these sites to circulating RBP4 is of great interest for understanding its biological function. In particular its aforementioned robust expression in adipose tissue and the observed correlation to serum levels in a variety of metabolic conditions (Yang et al., 2005) sparked the idea that adipose tissue may significantly contribute to blood RBP4 (Muoio and Newgard, 2005; Tamori et al., 2006).

The site of origin was elegantly addressed by a recent study, reporting that circulating RBP4 derives exclusively from hepatocytes. This was concluded from the observation that it was undetectable in blood of mice with a hepatocyte-specific RBP4 knockout (Thompson et al., 2017). Thus, RBP4 should be considered primarily a hepatokine rather than an adipokine, which is further supported by the finding that a modest liverspecific overexpression of RBP4 readily translates in increased serum levels (Muenzner et al., 2013; Fedders et al., 2018) and that chronic liver diseases in humans that interfere with the hepatic biosynthetic capacity lead to lower RBP4 in serum (Yagmur et al., 2007). Consistently, adiponectin promoter-driven overexpression of human RBP4 increased its protein levels in adipose tissue without leading to a major elevation of circulating RBP4 when mice were fed standard chow (Lee et al., 2016). Thus, in mice and most likely also in humans, probably all circulating RBP4 is liver-derived. However, it has been hypothesized that there are disease states or certain conditions that may allow extra-hepatic RBP4 to reach the circulation. The reasons for why hepatocyte-derived RBP4 reaches the circulation but not adipocyte-expressed RBP4 are currently unknown. This is even more puzzling since cultured adipocytes or fat explants readily secrete RBP4 into the culture media (Tsutsumi et al., 1992; Wei et al., 1997; Thompson et al., 2017). Notably, muscle-specific overexpression of human RBP4 rescued RBP4 levels in the circulation of RBP4-deficient mice, suggesting that also in vivo, non-hepatocyte expressed RBP4 can per se contribute to blood RBP4 (Quadro et al., 2002).

Besides the circulation, RBP4 is also found in other compartments such as the cerebrospinal fluid (CSF), most likely by its secretion from choroid plexus cells of the blood brain barrier (MacDonald et al., 1990; Duan and Schreiber, 1992).

It should be noted that not all commercially available kits quantify RBP4 reproducibly. When comparing different methods, including sandwich enzyme-linked immunosorbent assays and competitive enzyme-linked immunoassays, quantitative western blotting standardized to full-length RBP4 came out as the superior method for measuring RBP4 in serum (Graham et al., 2007).

\section{HEPATIC RETINOL MOBILIZATION BY RBP4}

Upon dietary uptake, retinoids, in form of retinyl esters, are together with other lipids packed into chylomicrons, and then released from the intestine into the lymphatic system (Goodman et al., 1965; Vogel et al., 1999). By the action of membrane-bound lipoprotein lipase (LPL), cells hydrolyze triglycerides and retinyl esters from these lipoproteins to meet their specific demands. Especially when RBP4's function is compromised, LPL-mediated uptake of lipoprotein-derived retinyl esters can be a significant alternative source for cellular retinoids (Quadro et al., 2004). Chylomicron remnants that are formed are then taken up by the liver which serves as the main site of retinoid storage. An alternative dietary source of retinoids are provitamin A carotenoids, whose transport, cellular uptake, and metabolism differs from these pathways and which are not the focus of this article. The reader is kindly referred to other excellent reviews on this topic (von Lintig, 2012; von Lintig et al., 2020).

RBP4's primary function is to mobilize retinol from liver (Figure 1). The liver hosts the bulk of retinoids of dietary origin as retinyl esters (Kane et al., 2008) in hepatic stellate 
cells, morphologically distinct and lipid droplets containing cells that are specialized in storing high concentrations of retinyl esters (Yamada et al., 1987). Stellate cells express lecithin retinol acyltransferase (LRAT), very likely the only enzyme to esterify retinol in these cells (Batten et al., 2004; Liu and Gudas, 2005; O'Byrne et al., 2005), and a number of potential lipases for retinyl ester hydrolysis to provide retinol for mobilization (Haemmerle and Lass, 2019; Wagner et al., 2020). Although it is not completely understood how retinol travels from stellate cells to hepatocytes and vice versa, it was shown that an absence of RBP4 did not prevent retinyl ester storage in stellate cells, implying RBP4-independent mechanisms at play (Quadro et al., 1999). For retinol mobilization into the circulation, however, RBP4 expression in hepatocytes is indeed required (Shirakami et al., 2012). Mice that lack RBP4 globally showed increased amounts of hepatic retinol and retinyl esters, whereas circulating retinol levels were decreased by almost 90\% (Quadro et al., 1999). Reciprocally, an acute overexpression of RBP4 specifically in liver increased serum retinol levels with a simultaneous reduction in liver retinyl esters (Muenzner et al., 2013), underlining the pivotal role of RBP4 expression in hepatocytes for mobilizing retinol into the circulation.

Notably, residual levels of retinol in the circulation of mice lacking RBP4 show that alternative carrier proteins are present, including albumin that can readily bind retinol (Muenzner et al., 2013). Moreover, retinyl esters are also found in liver-derived very low density lipoprotein (VLDL) and LDL (Krasinski et al., 1990), suggesting that either RBP4-independent pathways for mobilization from liver exist or that retinyl esters from dietary chylomicrons can be transferred by the action of cholesteryl ester transfer protein (CETP). Collectively, these pathways seem, at least partially, to compensate when RBP4 is dysfunctional or absent (Quadro et al., 1999, 2005) and maintaining a basal degree of retinoid delivery to target cells.

Hepatocytes release RBP4 bound to retinol (holo-RBP4) and the availability of retinol facilitates its secretion (Bellovino et al., 1999). Consistently, vitamin A-deficiency in rats decreases serum-RBP4 levels while inducing its accumulation in liver (Smith et al., 1975) and adding retinol to retinol-depleted hepatocytes increases RBP4 secretion (Dixon and Goodman, 1987). Before exiting the cell, RBP4 associates with the earlier mentioned prealbumin, also known as transthyretin (TTR), a tetrameric protein of $\sim 55 \mathrm{kDa}$ (Monaco et al., 1995; Naylor and Newcomer, 1999), forming a complex within the endoplasmic reticulum (ER) (Bellovino et al., 1996). Total lack of TTR or an acute, liver-specific depletion induced an accumulation of RBP4 in liver, suggesting that TTR enhances RBP4 secretion (Wei et al., 1995; Fedders et al., 2018). However, TTR seems not absolutely required since some RBP4 was still detectable in the circulation of TTR knockout mice and isolated hepatocytes with or without TTR expression secreted comparable amounts of RBP4 (van Bennekum et al., 2001). Moreover, despite strongly reduced serum RBP4 and retinol concentrations, TTR-deficient mice did not show any major alterations in tissue retinoid levels, including the liver and the eye (Wei et al., 1995), arguing against a limiting function of TTR in hepatic retinol mobilization and systemic homeostasis. Thus, TTR's primary effect on RBP4 is in regard to increasing its serum half-life by formation of a higher molecular weight complex that prevents renal filtration (van Bennekum et al., 2001). Intriguingly, TTR functions also as one of the specific transport proteins for thyroid hormone (Ingbar, 1963). The potential biological interplay of retinol and thyroid hormone transport via the liver-secreted RBP/TTR complex have not been fully dissected yet.

\section{RECEPTORS FOR RBP4}

The exact nature of an earlier postulated cell-surface receptor for RBP4 remained enigmatic until 2007, when Sun et al. identified 'stimulated by retinoic acid 6' (STRA6) as a cell surface receptor that transports retinol provided by holo-RBP4 across the cell membrane (Kawaguchi et al., 2007). Prior to this new function, it was already known that STRA6 contains several transmembrane domains and that its expression is inducible by atRA (Taneja et al., 1995). Strikingly, STRA6 mediates bi-directional retinol transport as well as exchange between intracellular binding proteins and extracellular RBP4, thereby balancing circulating RBP4 with import and export, metabolism, and storage of intracellular retinoids and counteracting states of both retinoid insufficiency or oversupply (Kawaguchi et al., 2012). TTR partially blocks the STRA6-mediated release of retinol from holo-RBP4 and may need to dissociate from the complex before RBP4 can bind STRA6 (Kawaguchi et al., 2011). Retinol uptake by STRA6 is coupled to intracellular binding and/or storage via cellular retinol binding protein 1 (CRBP1) and LRAT activity, respectively (Isken et al., 2008; Kawaguchi et al., 2011). Accordingly, free retinol present in the membrane blocks STRA6-catalyzed retinol release (Kawaguchi et al., 2011). A site-directed mutagenesis screen identified a characteristic loop in the structure of STRA6 that is responsible for the release of retinol from its binding pocket in the $\beta$-barrel core of RBP4 (Kawaguchi et al., 2008).

STRA6 is strongly expressed during embryonic development, in structures of blood-organ barriers, and organs that required high levels of retinoids, including the retinal pigment endothelium (RPE) and the female reproductive organs, testis, brain, and the kidney (Bouillet et al., 1997; Wu C. et al., 2009). In mice, differential promotor usage of the Stra6 gene gives rise to different mRNA transcripts that show distinct regulations by retinol deficiency, potentially encoding also a shorter, N-terminally truncated STRA6 protein (Laursen et al., 2015). Mice that lack STRA6 were viable but had a dramatic reduction of retinoids in the RPE as well as retina and suffered from impaired vision and irregular ocular morphology (Ruiz et al., 2012; Amengual et al., 2014). More recently, the structure of zebrafish STRA6 was solved by cryo-electron microscopy, revealing one intramembrane and nine transmembrane helices in an intricate dimeric assembly that forms a deep lipophilic cleft for retinol internalization into the membrane lipid bilayer (Chen et al., 2016). Unexpectedly, STRA6 was tightly bound by calmodulin, which, in conjunction with $\mathrm{Ca}^{2+}$, was shown to favor binding of apo-RBP4 and retinol export (Zhong et al., 2020; Figure 2A). Dissecting the biological significance of 


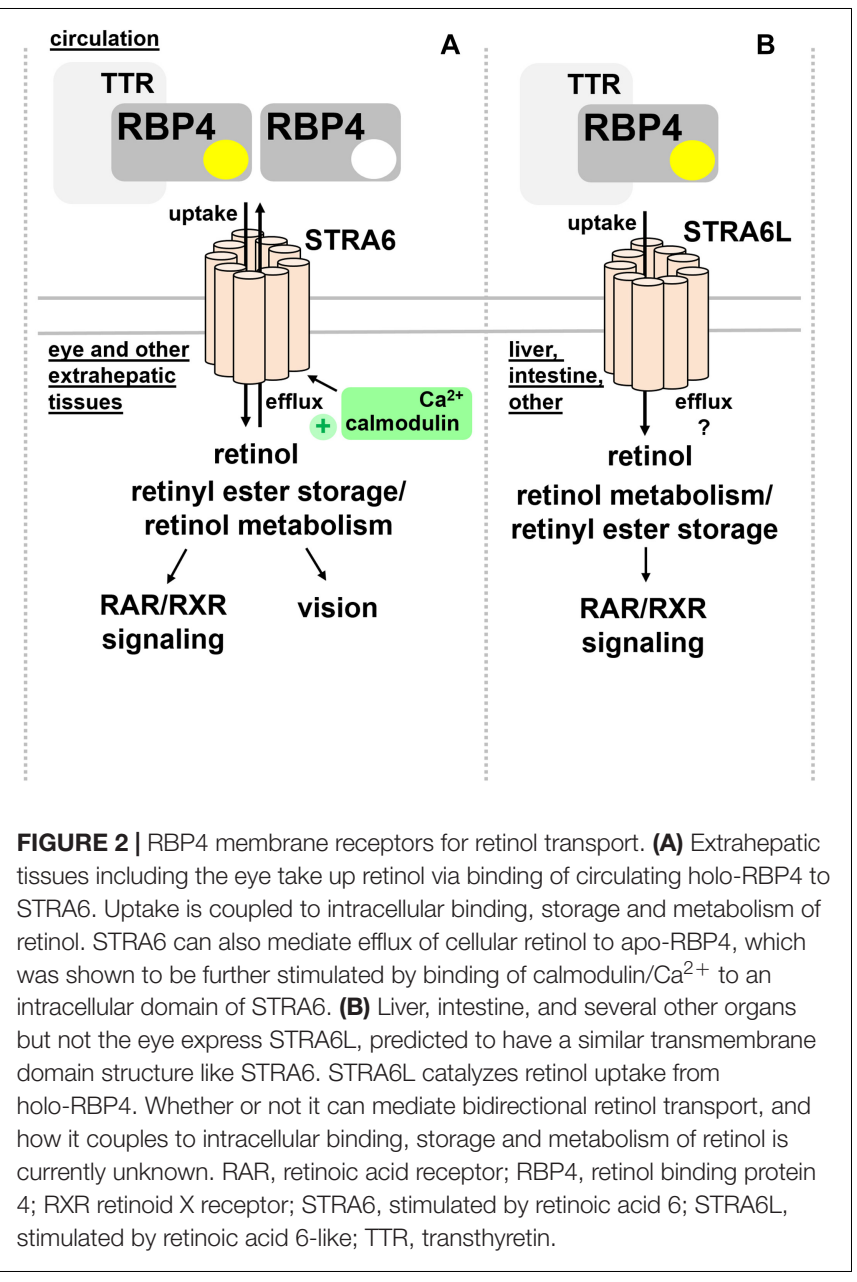

calmodulin/ $\mathrm{Ca}^{2+}$ on retinol transport by RBP4 and STRA6 may reveal an additional level of understanding of how this process is coordinated.

In addition to STRA6, a structurally related protein of about $20 \%$ overall homology acting as RBP4 receptor was identified in 2013 and designated first RBP4 receptor 2 (RBPR2) and later as 'stimulated by retinoic acid 6-like' (STRA6L) (Alapatt et al., 2013). Since it was known that retinol cycles between the circulation and liver and that expression of STRA6 is almost undetectable in this organ (Bouillet et al., 1997), the existence of another receptor was assumed. Indeed, STRA6L's expression is highest in liver, and somewhat lower in intestine and colon (Alapatt et al., 2013). In contrast to STRA6, STRA6L expression is suppressed by retinol and atRA. Furthermore, it is still unknown whether STRA6L can also mediate bidirectional retinol transport (Alapatt et al., 2013; Figure 2B). Functionally, STRA6L is required for development and function of the eye in zebrafish (Shi et al., 2017; Lobo et al., 2018; Solanki et al., 2020). Also in zebrafish, STRA6L is expressed in tissues involved in retinol uptake and storage, like intestinal enterocytes, hepatocytes, and pancreatic cells but not the eye itself. However, STRA6L mutant fish exhibit visual defects that are likely due to systemic vitamin A deficiency that was observed in these fish (Shi et al., 2017).
At this point, STRA6 and STRA6L are the only known specific receptors for RBP4. It should be pointed out that retinol uptake from circulating holo-RBP4 may also involve receptorindependent membrane passage/diffusion, in particular when receptor-mediated uptake is compromised (Berry et al., 2013).

\section{RBP4 CATABOLISM}

After its dissociation from TTR and retinol release, retinol-free apo-RBP4 in the circulation is filtrated by the kidney. More than $99 \%$ of that is reabsorbed by the proximal renal tubule, which renders urinary RBP4 a highly sensitive marker for tubular dysfunction (Bonventre et al., 2010). Tubular reabsorption of RBP4 is mediated by the megalin-cubilin receptor complex (Christensen et al., 1999; Raila et al., 2005). Besides its endocytic uptake, RBP4 staining in lysosomes, endoplasmic reticulum, Golgi, and basal vesicles suggest basolateral RBP4 secretion by these cells via a degradation-synthesis cycle (Christensen et al., 1999). Strikingly, kidney-specific megalin deletion in mice, besides inducing loss of RBP4 in the urine, led also to urinary retinol excretion and reduced hepatic retinol and retinyl esters, suggesting a more complex and rather unexplored role of the kidney in retinoid homeostasis (Raila et al., 2005).

\section{RBP4 LOSS-AND GAIN-OF-FUNCTION INDUCED PATHOLOGIES IN MICE}

Embryonic development. Mice with genetic deletion of RBP4 exhibit very low retinol concentrations in their circulation (Quadro et al., 1999). However, they give birth to viable embryos that show rather mild and transient developmental abnormalities of the heart (Wendler et al., 2003), a much less severe phenotype as one would have predicted from the relevance of vitamin A for the developing organism. However, this is only observed when mice were fed diets with sufficient vitamin A and implying RBP4-independent pathways for retinoid delivery already discussed above. Reducing the dietary intake of vitamin A in females lacking RBP4 before and during pregnancy has fatal consequences on embryonic development (Quadro et al., 2005). Feeding a vitamin A-deficient diet $(<0.22$ $\mathrm{IU} / \mathrm{g}$ ), severe embryonic malformations were observed, including smaller embryo size, undetectable or abnormal midfacial regions and forelimbs, and exencephaly (Quadro et al., 2005). These characteristics are in line with the severe fetal vitamin A deficiency syndrome and overlap with the phenotypes of mice with retinoid receptor knockouts (Mark et al., 2009).

Vision. Mice on a mixed genetic background (129xC57BL/6J) that lack RBP4 show impaired retinal function and visual acuity during the first couple of months but develop normal vision by 4-5 months of age when fed standard chow, in this particular study $22 \mathrm{IU}$ of retinol/g (Quadro et al., 1999). However, when maintained on a vitamin A-deficient diet after weaning $(<0.22$ $\mathrm{IU} / \mathrm{g})$, vision of RBP4-deficient mice $(129 \mathrm{xC} 57 \mathrm{BL} / 6 \mathrm{~J})$ further deteriorated whereas that of control mice was not compromised. A more recent study suggests that visual defects upon loss 
of RBP4 are even more pronounced and become chronic on a pure $\mathrm{C} 57 \mathrm{BL} / 6$ genetic background even when feeding a vitamin A sufficient diet with $\sim 15 \mathrm{IU} / \mathrm{g}$ (Shen et al., 2016). Transgenic expression of human RBP4 in muscle (Quadro et al., 2002) or from the murine $R b p 4$ gene locus (Liu et al., 2017) rescued serum retinol levels and suppressed visual defects due to loss of endogenous RBP4. These results demonstrate that visual performance depends on RBP4-mediated retinol transport but also highlights the aforementioned existence of alternative, although less efficient, pathways for the eye to acquire retinoids (Vogel et al., 2002). It also underlines that most other tissues in the body are less dependent on RBP4-mediated retinol delivery, especially when dietary retinoid supply is ample. This notion is further supported by the phenotype of mice lacking the RBP4 receptor STRA6, in which rod photoreceptor outer and inner segment length as well as cone cell numbers were reduced, as were scotopic and photopic responses (Ruiz et al., 2012; Amengual et al., 2014). Besides visual defects, these mice showed no other major vitamin A-related abnormalities (Berry et al., 2013), somewhat similar to RBP4-deficient mice. Notably, also transgenic overexpression of human RBP4 in muscle of mice can lead to progressive retinal degeneration, although this appears to be independent of alterations in retinoids and more likely to be mediated by retinal neuroinflammation (Du et al., 2015, 2017).

Insulin sensitivity and glucose tolerance. Elevated RBP4 in the circulation of type 2 diabetic patients was reported many years ago (Basualdo et al., 1997; Abahusain et al., 1999) but it took until 2005, when a causal link between circulating RBP4 and insulin resistance was presented: Yang et al. showed, besides increased RBP4 in blood of multiple insulin resistant mouse models, that RBP4-deficient mice were less prone to develop insulin resistance (Yang et al., 2005). Moreover, transgenic overexpression of human RBP4 or injection of recombinant human RBP4 in wild-type mice caused glucose intolerance and insulin resistance. Since RBP4 expression was increased in adipose tissue but not liver, these findings led to the hypothesis that RBP4 acts as an adipokine, linking obesity with insulin resistance. Intriguingly, serum RBP4 correlated positively with adipose RBP4 mRNA and intra-abdominal fat mass and inversely with insulin sensitivity also in humans (Klöting et al., 2007) and was lowered by exercise (Graham et al., 2006). However, at least in mice and as already pointed out above, circulating RBP4 is derived primarily from liver and not adipose tissue. Mechanistically, RBP4 was shown to induce expression of the gluconeogenic enzyme phosphoenolpyruvate carboxykinase in liver and to impair insulin signaling in muscle (Yang et al., 2005). However, follow-up studies by the same laboratory implicated the immune system, in particular antigen-presenting cells, such as dendritic cells, macrophages, and also CD4 T cells as the drivers of an inflammatory response that is induced by RBP4 within adipose tissue (Norseen et al., 2012; MoraesVieira et al., 2014, 2016, 2020). Strikingly, this inflammatory reaction was independent of RBP4's association with retinol (Norseen et al., 2012) and mediated by an activation of toll-like receptors 2/4 (TLR2/4) and proinflammatory cytokine secretion from macrophages, involving nuclear factor $\kappa-B(N F \kappa B)$, c-Jun
$\mathrm{N}$-terminal kinases (JNK), and interleukin $1 \beta$ (Moraes-Vieira et al., 2014, 2020; Figure 3A).

An alternative functional model was suggested by Berry et al. (2011), where holo-RBP4's binding to STRA6 triggers receptor phosphorylation close to its C-terminus and the recruitment and activation of Janus kinase 2 (JAK2) and the signal transducer and activator of transcription 5 (STAT5) (Figure 3B). Interestingly, neither retinol nor retinol free apo-RBP4 were able to induce STAT5 phosphorylation. Activated STAT5 then leads to the upregulation of genes which are known to inhibit insulin signaling, such as suppressor of cytokine signaling 3 (SOCS3) (Berry et al., 2011). Follow-up studies provided evidence that activation of JAK/STAT by STRA6 requires transfer of retinol from holo-RBP to an intracellular acceptor, such as CRBP1 or LRAT (Berry et al., 2012b). TTR's association with holoRBP4 prevented STRA6 binding and, subsequently, induction of JAK/STAT signaling (Berry et al., 2012a). These findings were corroborated by the observation that injected recombinant holoRBP4 failed to induce JAK/STAT or impair insulin signaling in mice lacking STRA6 (Berry et al., 2013).

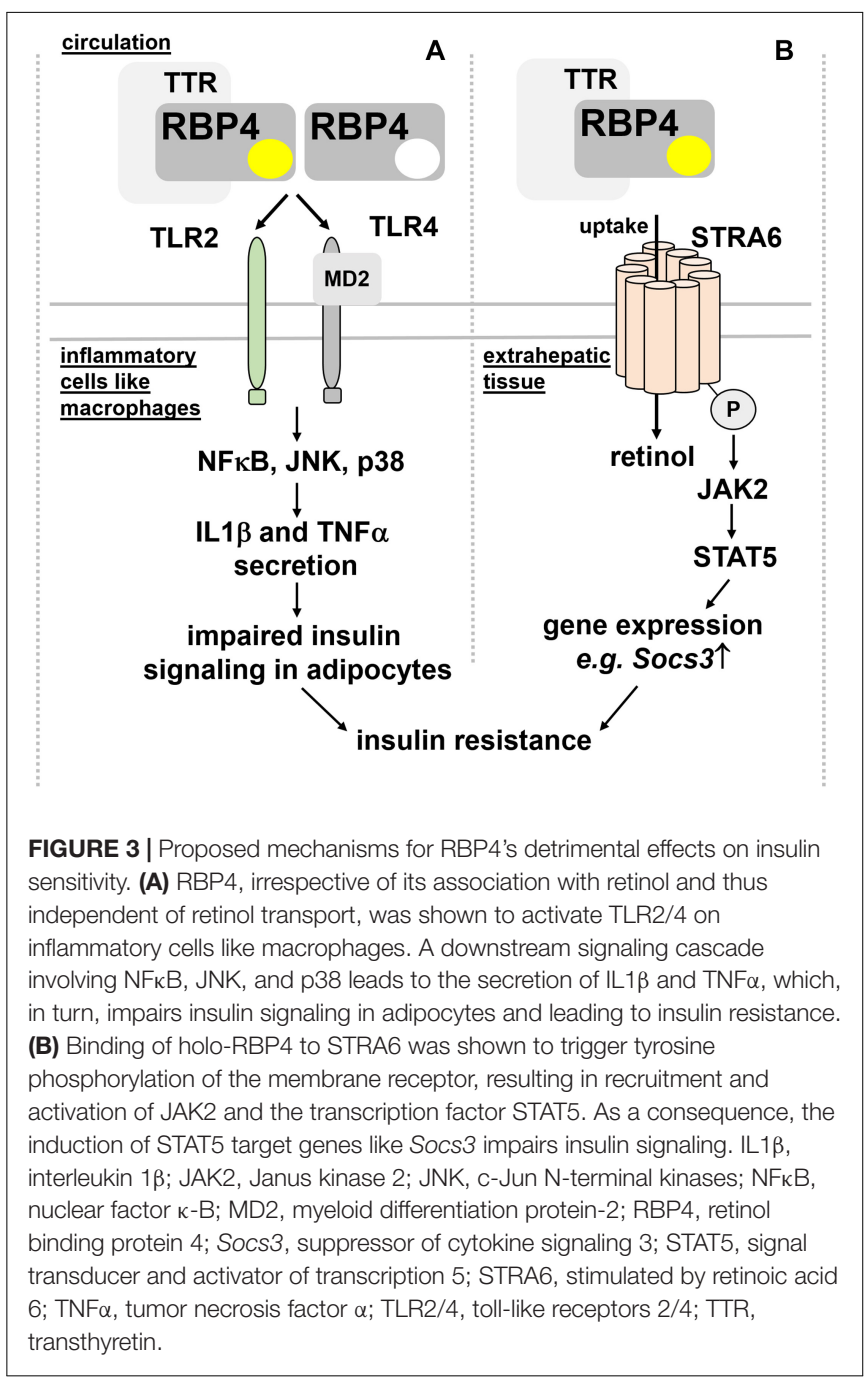


Hence, RBP4's causal role in inducing insulin resistance is still vividly debated within the field (Fedders et al., 2015). Although elevated levels of circulating RBP4 in states of insulin resistance and type 2 diabetes were reproduced by the majority of studies and by many independent laboratories, the underlying reasons for this elevation, and whether or not RBP4 is indeed actively contributing to insulin resistance is still under investigation. A few examples of unanswered issues for the reader's consideration are described in the following sentences. For instance, not all studies identified elevated expression of RBP4 in adipose tissue of obese patients (Janke et al., 2006), and instead of adipose tissue expression, kidney function was proposed as major determinant of its serum levels, which is known to deteriorate upon the onset of type 2 diabetes and thus may lead to an accumulation of RBP4 in the blood (Raila et al., 2007; Henze et al., 2008). Other studies failed to reproduce improved insulin sensitivity and glucose tolerance in RBP4-deficient mice when fed a high-fat diet (Motani et al., 2009). Also mouse models that increase circulating RBP4 levels by an extent that is comparable to insulin resistant states by an acute or long-term liver-specific overexpression of murine RBP4 instead of the human protein did not observe an impairment in insulin responses and glucose tolerance (Muenzner et al., 2013; Fedders et al., 2018). From a physiological perspective, how can the lipocalin RBP4 that is so strongly expressed in liver and circulating at rather high levels in the blood become an inflammatory stressor upon a 2-3 fold elevation that is observed in these states? Are there yet unidentified post-translational modifications of RBP4 that occur upon extended serum half-life that could mediate this? Moreover, is retinol transport just a bystander or an active participant in these presumed RBP4 effects? Why are some of the metabolic effects of transgenically elevated RBP4 in mice seen with human but not the murine protein? Further research is needed to address these questions for building a consensus on this important, but continuously controversial topic.

Adipose tissue lipolysis and hepatic fat content. Adipose tissue-specific overexpression of human RBP4 in mice induces hepatic steatosis, despite an absence of changes in total RBP4 levels in the circulation or alterations in retinoid concentrations (Lee et al., 2016). Hepatic steatosis was accompanied by glucose intolerance and elevated concentrations of non-esterified fatty acids in plasma, which were shown to contribute to hepatic triglyceride accumulation. Feeding a high-fat diet aggravated the RBP4-induced metabolic disturbances in these mice. These findings indicate that locally expressed RBP4 stimulates adipose tissue lipolysis and fatty acid release, which subsequently triggers hepatic steatosis. Whether this is due to direct effects of RBP4 on fatty acid handling or indirect, via an induction of proinflammatory cytokines like tumor necrosis factor $\alpha$ (TNF $\alpha)$ or changes in local retinoid homeostasis, will be interesting to dissect (Lee et al., 2016). Additional insights come from another study showing that treatment of human adipocytes with RBP4 directly stimulated lipolysis and that, when co-cultured with macrophages, pro-inflammatory cytokines contribute to this by interfering with the insulin-dependent suppression of lipolysis (Kilicarslan et al., 2020). In agreement with RBP4's stimulating effect on lipolysis are the reported lower levels of non-esterified fatty acids in serum of RBP4-deficient mice (Yang et al., 2005).

Cold tolerance. Exposing mice or humans to low temperatures increases plasma concentrations of RBP4 and retinol (Fenzl et al., 2020). In mice, this coincides with an elevation of Rbp4 mRNA expression in liver (Fenzl et al., 2020), which may indicate increased retinol mobilization from liver into the blood stream for supporting the adaptation to cold. Indeed, mice lacking RBP4 failed to induce thermogenic reprogramming of their subcutaneous adipose tissue, rendering these mice more sensitive to cold and dropping of their body temperature. Retinol induced thermogenic gene expression also in human white adipocytes and increased mitochondrial respiration (Fenzl et al., 2020). Thus, elevated retinol mobilization by RBP4 from liver upon the exposure to cold may be required for an adequate thermogenic adaptation of specific white adipose tissues depots in order to maintain body core temperature, which so far has not been formally tested. Moreover, loss of RBP4 in mice was associated with reduced phosphorylation of hormone sensitive lipase during the exposure to cold (Fenzl et al., 2020), a lipolytic enzyme that is activated by phosphorylation and essential for adequate fatty acid release from white adipose tissue (Stralfors and Belfrage, 1983). Providing fatty acids is required for uncoupling protein-induced thermogenesis (Schreiber et al., 2017). Thus, RBP4's function during cold exposure may be linked to the above described stimulating effects on lipolysis, thereby ensuring fatty acid supply to brown adipose tissue as fuel for functional uncoupling protein-mediated non-shivering thermogenesis.

Cardiovascular system and blood pressure. Circulating RBP4 levels also correlate with blood pressure and cardiovascular disease (Solini et al., 2009; Meisinger et al., 2011; Sun et al., 2013; Li et al., 2019), potentially also secondary to decreased renal clearance due to hypertensive nephropathy (Majerczyk et al., 2017). Strikingly, systolic and diastolic blood pressure were lower in the RBP4-knockout mice and higher in the RBP4-overexpressing mice compared with the corresponding wild-type littermates (Kraus et al., 2015), suggesting indeed a functional role of RBP4 in the control of blood pressure. RBP4-deficient mice were partially protected from angiotensin 2-induced hypertension and cardiac hypertrophy. Further studies are needed to interrogate whether these effects are dependent on retinol transport and to delineate the underlying mechanisms in more detail. In this regard, effects of RBP4 on endothelial cells are likely to be involved since carbacholinduced, and therefore endothelium-dependent, vasodilation of carotid arteries ex vivo was slightly enhanced or reduced in RBP4 knockout and overexpressing mice, respectively (Kraus et al., 2015).

Behavior and neuropathology. Besides its expression in various regions of the central nervous system and associated structures (MacDonald et al., 1990; Duan and Schreiber, 1992; Wu C. et al., 2009), very little is known about RBP4's role in the brain. Interestingly, RBP4-deficient mice have decreased locomotor activity and increased anxiety-like behavior. At a 
structural level these mice show neuronal loss and gliosis in the cortex and hippocampus and a reduction in proliferating neuroblasts in the subventricular zone (Buxbaum et al., 2014). It thus appears that altered vitamin A transport affects brain development and neuronal function, thereby altering behavior. Moreover, these neuropathological alterations might complicate the interpretations of other phenotypes observed in whole body RBP4-deficient mice. Of note, Buxbaum et al. investigated TTR-deficient mice in parallel and found some, but not complete overlap in the above described phenotypes, which is in accordance with the interdependent transport characteristics of the RBP/TTR complex.

\section{PATHOLOGIES ASSOCIATED WITH RBP4 MUTATIONS IN HUMANS}

So far, null mutations of RBP4 have not been characterized in humans (Zhong et al., 2014), which may suggest that in contrast to mice, complete absence of RBP4 is incompatible with embryonic survival, regardless of maternal vitamin A intake. It is interesting to note that compared to rodents, humans seem to be much more sensitive to dysregulated retinoid homeostasis and retinoid toxicity associated with random retinoid diffusion (Nau, 2001), which could be a likely consequence of dysfunctional RBP4 variants.

Vision. Two mutations p.I59N and p.G93D, corresponding to I41N and G75D of RBP4 after cleavage of the signal peptide of the mature protein, were associated with night blindness and modest retinal dystrophy without apparent effects on growth in compound heterozygous sisters (Biesalski et al., 1999; Seeliger et al., 1999). Both mutations were associated with reduced plasma RBP4 and retinol concentrations most likely due to reduced stability of the retinol-RBP4 complex (Folli et al., 2005). Another two missense mutations, p.A73T and p.A75T, were identified to cause autosomal dominant congenital eye malformations, including microphthalmia, anophthalmia, and coloboma (MAC) disease and with a maternal penetrance significantly greater than paternal penetrance (Chou et al., 2015). Similar to p.I59N and p.G93D, both mutant proteins bound retinol rather poorly, but strikingly, the unliganded mutant proteins were found to occupy STRA6 with much higher affinity than wild-type RBP4, and consequently are likely to disrupt delivery of vitamin A to target cells in accordance with a dominant-negative effect (Chou et al., 2015). Rare bi-allelic mutations (c.248 + $1 \mathrm{G}>\mathrm{A}$ ) of RBP4 were identified in a patient with retinal dystrophy and ocular coloboma (Khan et al., 2017). A homozygous splice site variant in $R B P 4$ (c. $111+1 \mathrm{G}>\mathrm{A}$ ) was found to cause retinal dystrophy and developmental abnormalities (Cukras et al., 2012). Both mutations were associated with low or undetectable RBP4 levels in the circulation. Another homozygous mutation $(c .67 \mathrm{C}>\mathrm{T}$ ) of $R B P 4$, predicted to encode an early stop codon (p.Arg23*) and resulting a premature termination of translation, associated with retinitis pigmentosa (Cehajic-Kapetanovic et al., 2020). Although assumed to yielding no functional RBP4, whether or not the latter mutation represents a null mutation in homozygosity is currently unclear.
It is interesting to note that mutations in the $\mathrm{RBP} 4$ receptor STRA6 in humans cause a wide array of malformations including anophthalmia, congenital heart defects, diaphragmatic hernia, alveolar capillary dysplasia, lung hypoplasia, and intellectual disability, also referred to as Matthew-Wood syndrome (Golzio et al., 2007; Pasutto et al., 2007; Chassaing et al., 2009). Why the human phenotype is much more severe than STRA6 loss-offunction in mice is still under investigation but may be linked to the aforementioned differences in sensitivities to retinoid toxicity between humans and rodents.

Other conditions. Although also restricted to very few case studies, some of the above described RBP4 mutations were associated with acne vulgaris, osteoarthritis, and hypercholesterolemia, conditions that can be linked to dysregulated retinoid homeostasis (Seeliger et al., 1999; Cukras et al., 2012; Khan et al., 2017; Cehajic-Kapetanovic et al., 2020).

\section{RBP4 POLYMORPHISMS IN HUMANS AND DISEASE ASSOCIATION}

Not unexpectedly, single-nucleotide polymorphisms of RBP4 exist that associate with circulating retinol levels (Mondul et al., 2011). In regard to disease states, polymorphisms of $R B P 4$ were shown to associate with the risk for coronary artery disease (Wan et al., 2014), childhood obesity and cardiovascular risk factors (Codoñer-Franch et al., 2016), with plasma RBP4 levels and hypertriglyceridemia risk in Chinese Hans (Wu Y. et al., 2009), serum HDL (Shea et al., 2010), the risk for gestational diabetes (Hu et al., 2019), body mass index (Munkhtulga et al., 2010), insulin resistance (Kovacs et al., 2007), and type 2 diabetes (Craig et al., 2007; Munkhtulga et al., 2007; van Hoek et al., 2008). As delineated above, genetic mouse models seem to support a causative role for RBP4 in some of these conditions.

\section{PHARMACOLOGICAL APPROACHES TO LOWER CIRCULATING RBP4}

The notion that elevated RBP4 in the circulation may contribute to certain pathologies sparked renewed interest in RBP4lowering therapies. The retinoid fenretinide, first produced in the United States in the 1960s, is a synthetic amide derivative of atRA and has antiproliferative and apoptotic effect in certain tumor cells (Ulukaya and Wood, 1999). Fenretinide was also shown to bind RBP4, to affect its hepatic secretion, and to sterically disrupt complex formation with TTR (Malpeli et al., 1996; Holven et al., 1997). As a consequence of the latter, renal clearance of RBP4 is increased and its serum concentration and also that of retinol decline (Formelli et al., 1993; Schaffer et al., 1993). This may be why in humans, fenretinide administration can lead to impaired visual adaptation to darkness (Decensi et al., 1994).

Treating high-fat diet fed mice with fenretinide for 6 weeks normalized circulating RBP4 levels to that of mice fed normal chow, at the same time improving insulin action and glucose tolerance (Yang et al., 2005), which is in support of RBP4's detrimental effect on glucose homeostasis. Moreover, 
TABLE 1 | Major findings from mouse models and human mutations of RBP4.

\begin{tabular}{lll}
\hline Species & $\begin{array}{l}\text { Mouse model or } \\
\text { human mutation }\end{array}$ & Findings \\
\hline
\end{tabular}

Mouse Global RBP4 knockout

Mouse Overexpression of human RBP4 under the control of the mouse muscle creatine kinase promoter

Mouse

Mouse

Acute liver-specific overexpression of murine RBP4

Adipocyte-specific overexpression of human RBP4

Mouse Hepatocyte-specific knockout of RBP4

$\begin{array}{ll}\text { Mouse } & \begin{array}{l}\text { Human } R B P 4 \text { open } \\ \text { reading frame in the } \\ \text { mouse } R b p 4 \text { locus } \\ \text { Mouse }\end{array} \\ & \begin{array}{l}\text { Long-term liver-specific } \\ \text { overexpression of } \\ \text { murine RBP4 }\end{array}\end{array}$

circulating retinol levels decreased by 90\% (Quadro et al., 1999)

increased contents of retinol and retinyl esters in liver at an age of 5 months (Quadro et al., 1999)

impaired retinal function and visual acuity during first months of life that normalize after 4-5 months when fed a vitamin A-sufficient diet (Quadro et al., 1999), analyzed on mixed 129xC57BL/6J genetic background viable embryos with mild and transient developmental abnormalities of the heart (Wendler et al., 2003) increased utilization of lipoprotein-derived retinyl esters (Quadro et al., 2004) increased insulin sensitivity (Yang et al., 2005) lower circulating levels of non-esterified fatty acids (Yang et al., 2005) feeding a vitamin A-reduced diet before and/or during pregnancy leads to severe embryonic malformations (smaller size, undetectable or abnormal midfacial regions and forelimbs, and exencephaly) (Quadro et al., 2005) no effect on insulin sensitivity and glucose tolerance on normal chow and after feeding a high-fat diet (Motani et al., 2009)

decreased locomotor activity (Buxbaum et al., 2014)

increases anxiety-like behavior (Buxbaum et al., 2014)

neuronal loss (Buxbaum et al., 2014)

gliosis in the cortex and hippocampus (Buxbaum et al., 2014)

reduction in proliferating neuroblasts in the subventricular zone (Buxbaum et al., 2014)

lower blood pressure (Kraus et al., 2015)

partially protected from angiotensin 2-induced hypertension (Kraus et al., 2015)

reduced cardiac hypertrophy (Kraus et al., 2015)

serum retinol levels below detection threshold (Shen et al., 2016), analyzed on pure C57BL/6 genetic background more severe and persistent visual impairments (Shen et al., 2016), analyzed on pure C57BL/6 genetic background improved insulin responses and lower adipose tissue inflammation and CD4 T-cell activation when fed normal chow or high-fat diet (Moraes-Vieira et al., 2016), analyzed after feeding a low vitamin A diet (4 IU/g) for 4-5 generations prior to characterization

lower body core temperature when exposed to cold (Fenzl et al., 2020)

reduced thermogenic activation and hormone sensitive lipase activity in subcutaneous white adipose tissue upon cold exposure (Fenzl et al., 2020)

rescue of RBP4 and retinol levels in circulation when crossed into RBP4-deficient mice (Quadro et al., 2002)

suppression of visual defects when crossed into RBP4-deficient mice (Quadro et al., 2002)

insulin resistant at 12 weeks of age (Yang et al., 2005)

progressive retinal degeneration (Du et al., 2015)

no effect on serum insulin levels or insulin sensitivity (Du et al., 2015)

higher blood pressure (Kraus et al., 2015)

impaired glucose tolerance and insulin sensitivity and increased adipose tissue inflammation (Moraes-Vieira et al., 2016, 2020)

increased serum RBP4 and retinol levels and RAR activation in epididymal white adipose tissue (Muenzner et al., 2013)

decreased liver retinyl ester levels (Muenzner et al., 2013)

glucose tolerance not impaired (Muenzner et al., 2013)

increased RBP4 protein levels in adipose tissue (Lee et al., 2016)

circulating RBP4 and retinol levels unaltered when fed normal chow, increased when fed high-fat diet (Lee et al., 2016)

glucose intolerance and hepatic steatosis (Lee et al., 2016)

elevated concentrations of non-esterified fatty acids in plasma (Lee et al., 2016)

increased weight gain when feeding a high-fat diet (Lee et al., 2016)

elevated non-esterified fatty acid uptake and increased gluconeogenic gene expression in liver (Lee et al., 2016)

signs of increased visceral adipose tissue inflammation and altered retinoid homeostasis in liver (Lee et al., 2016)

RBP4 undetectable and retinol reduced by more than 93\% in serum (Thompson et al., 2017)

hepatic retinol and retinyl ester levels unchanged (Thompson et al., 2017)

moderately increased body weights, weight gain, and fat mass when fed a high-fat/high-sucrose diet (Thompson et al., 2017)

no alterations in insulin sensitivity or glucose tolerance on control or high-fat/high-sucrose diet (Thompson et al., 2017)

rescue of plasma RBP4 levels, of retinol levels and retinal function when crossed into RBP4-deficient mice (Liu et al., 2017), analyzed after backcrossing to C57BL/6 genetic background

increased serum RBP4 and retinol levels (Fedders et al., 2018)

liver retinyl ester levels unchanged (Fedders et al., 2018)

insulin response and glucose tolerance not impaired on either normal chow or high-fat diet (Fedders et al., 2018) 
TABLE 1 | Continued

\begin{tabular}{|c|c|c|}
\hline Species & $\begin{array}{l}\text { Mouse model or human } \\
\text { mutation }\end{array}$ & Findings \\
\hline Human & $\begin{array}{l}\text { Compound heterozygous } \\
\text { p.I59N and p.G93D }\end{array}$ & $\begin{array}{l}\text { Night blindness (Biesalski et al., 1999; Seeliger et al., 1999) } \\
\text { modest retinal dystrophy (Biesalski et al., 1999; Seeliger et al., 1999) } \\
\text { undetectable RBP4 and reduced retinol concentrations in serum (Seeliger et al., 1999) }\end{array}$ \\
\hline Human & $\begin{array}{l}\text { Homozygous } \\
\text { c. } 111+1 \mathrm{G}>\mathrm{A}\end{array}$ & $\begin{array}{l}\text { Retinal dystrophy (Cukras et al., 2012) } \\
\text { developmental abnormalities (Cukras et al., 2012) } \\
\text { undetectable RBP4 and reduced retinol concentrations in serum (Cukras et al., 2012) }\end{array}$ \\
\hline Human & Bi-allelic c. $248+1 \mathrm{G}>\mathrm{A}$ & $\begin{array}{l}\text { Retinal dystrophy (Khan et al., 2017) } \\
\text { ocular coloboma (Khan et al., 2017) } \\
\text { undetectable RBP4 levels in serum (Khan et al., 2017) }\end{array}$ \\
\hline Human & Homozygous c.67 C > T & Retinitis pigmentosa and childhood acne vulgaris (Cehajic-Kapetanovic et al., 2020) \\
\hline
\end{tabular}

long-term treatment with fenretinide for several months prevented high-fat diet induced obesity, insulin resistance, and hepatic steatosis, whereas, unexpectedly, some of these beneficial effects were also observed in mice lacking RBP4 (Preitner et al., 2009), proposing also RBP4-independent mechanisms at play. Indeed, follow-up studies implied direct regulation of retinoid homeostasis genes by fenretinide as a likely mechanism for its metabolic benefits (McIlroy et al., 2013). Moreover, lowering RBP4 by fenretinide was dependent on the presence of LRAT, which hints toward even more complex effects of this compound (Amengual et al., 2012). Fenretinide has also been used in human trials for age-related macular degeneration with some positive outcome but limited efficacy (Mata et al., 2013). RBP4 lowering is thought to limit the accumulation of lipofuscin bisretinoids in the RPE, a process known to contribute to a variety of degenerative retinal diseases (Radu et al., 2005). However, as a retinoid, fenretinide is accompanied by a problematic safety profile including teratogenicity.

Another small molecule RBP4 ligand is A1120, which, in contrast to fenretinide, is a non-retinoid compound, bearing no similarities with atRA. A1120 disrupts the RBP4 and TTR complex by inducing a conformational change of the interaction interface and potently lowers serum RBP4 and retinol (Motani et al., 2009). In high-fat diet fed mice, both fenretinide and A1120 lowered serum RBP4 but only fenretinide improved insulin responses and glucose tolerance, which let the authors argue that fenretinide's effects are independent of lowering RBP4 (Motani et al., 2009). By lowering retinol levels in serum and its nonretinoid nature, which may confer a more favorable safety profile compared to fenretinide, also A1120 is an investigational therapy for Stargardt macular dystrophy (Dobri et al., 2013; Hussain et al., 2018). Moreover, human RBP4 was shown to interact with engineered RBP4 protein scaffolds in an A1120-dependent manner, allowing for a synthetic and conformation-specific ON-switch system with a broad potential for pharmacological applications (Zajc et al., 2020).

BPN-14136 is another non-retinoid compound that disrupts the RBP4 and TTR complex with the potential to treat atrophic age-related macular degeneration and Stargardt disease (Cioffi et al., 2014). Interestingly, a BPN-14136 derivative was able to lower RBP4 and partially prevent high-fat diet induced obesity and hepatic steatosis in mice with adipose tissue-specific transgenic overexpression of human RBP4 described above (Cioffi et al., 2019).

\section{INTERACTION OF RBP4 WITH NON-RETINOID LIGANDS}

Whether endogenously expressed RBP4 transports non-retinoid ligands is currently unknown. Clues come from Nanao et al., who presented RBP4 crystal structures that contain expression host-derived oleic and linoleic acid in its ligand binding pocket, suggesting that RBP4 can indeed bind fatty acids [Protein data bank ID (Berman et al., 2000): 2WQ9 (Nanao et al., 2010), 2WR6 (Huang et al., 2010)]. Another study analyzed crystal structures of retinol-free RBP4 purified from human plasma, urine, or amniotic fluid and confirmed its binding to certain fatty acids. This included palmitic acid, which could be purified from RBP4 in human urine (Perduca et al., 2018). Moreover, palmitic and also linoleic acid, among others, were able to replace ${ }^{3} \mathrm{H}$-retinol from human RBP4 (Cioffi et al., 2019). Thus, RBP4 may be a physiologically relevant binding and transport protein for fatty acids. One could hypothesize that this may actually be involved in some of the aforementioned effects on glucose and fatty acid homeostasis and should be tested in future research.

\section{CONCLUDING REMARKS}

Much has been learned about RBP4's function in health and disease since its discovery more than 50 years ago. Extraordinary progress was made by generating and analyzing transgenic mouse models, in particular mice that lack RBP4 (Quadro et al., 1999), and by studying human mutations. Major findings from these studies are summarized in Table 1. What becomes obvious is that transport of retinol by RBP4 is the single most important route for its distribution in the body although, especially in mice, evolutionary pressure has led to the alternative delivery 
pathways to compensate for RBP4 dysfunction as a backup plan for the organism. This is also in accordance with the fundamental role of vitamin A for cell homeostasis. As pointed out in the introductory section, development of the eye and visual function show the highest dependence on the supply of retinol by RBP4, which is mirrored by the phenotypes of transgenic mouse models and the consequences of mutations in humans, and also therapeutic strategies that target this lipocalin. Besides mobilizing retinol from liver, its role within other tissues is much less well explored. Tissue-specific knockout mouse models of RBP4 may help to decipher new biological aspects. Together with potential functions beyond transporting retinol, as discussed in this review, the next decades will warrant many more exciting findings for a more complete picture of RBP4's biology.

\section{REFERENCES}

Abahusain, M. A., Wright, J., Dickerson, J. W., and de Vol, E. B. (1999). Retinol, alpha-tocopherol and carotenoids in diabetes. Eur. J. Clin. Nutr. 53, 630-635. doi: $10.1038 /$ sj.ejcn. 1600825

Alapatt, P., Guo, F., Komanetsky, S. M., Wang, S., Cai, J., Sargsyan, A., et al. (2013). Liver retinol transporter and receptor for serum retinol-binding protein (RBP4). J. Biol. Chem. 288, 1250-1265. doi: 10.1074/jbc.M112.369132

Amengual, J., Golczak, M., Palczewski, K., and von Lintig, J. (2012). Lecithin:retinol acyltransferase is critical for cellular uptake of vitamin A from serum retinolbinding protein. J. Biol. Chem. 287, 24216-24227. doi: 10.1074/jbc.M112. 353979

Amengual, J., Zhang, N., Kemerer, M., Maeda, T., Palczewski, K., and Von Lintig, J. (2014). STRA6 is critical for cellular vitamin A uptake and homeostasis. Hum. Mol. Genet. 23, 5402-5417. doi: 10.1093/hmg/ddu258

Basualdo, C. G., Wein, E. E., and Basu, T. K. (1997). Vitamin A (retinol) status of first nation adults with non-insulin-dependent diabetes mellitus. J. Am. Coll. Nutr. 16, 39-45. doi: 10.1080/07315724.1997.10718647

Batten, M. L., Imanishi, Y., Maeda, T., Tu, D. C., Moise, A. R., Bronson, D., et al. (2004). Lecithin-retinol acyltransferase is essential for accumulation of alltrans-retinyl esters in the eye and in the liver. J. Biol. Chem. 279, 10422-10432. doi: 10.1074/jbc.M312410200

Bellovino, D., Lanyau, Y., Garaguso, I., Amicone, L., Cavallari, C., Tripodi, M., et al. (1999). MMH cells: an in vitro model for the study of retinol-binding protein secretion regulated by retinol. J. Cell Physiol. 181, 24-32. doi: 10.1002/(SICI) 1097-4652(199910)181:1<24::AID-JCP3<3.0.CO;2-0

Bellovino, D., Morimoto, T., Tosetti, F., and Gaetani, S. (1996). Retinol binding protein and transthyretin are secreted as a complex formed in the endoplasmic reticulum in HepG2 human hepatocarcinoma cells. Exp. Cell Res. 222, 77-83. doi: 10.1006/excr.1996.0010

Berman, H. M., Westbrook, J., Feng, Z., Gilliland, G., Bhat, T. N., Weissig, H., et al. (2000). The protein data bank. Nucleic Acids Res. 28, 235-242. doi: 10.1093/nar/ 28.1.235

Berry, D. C., Croniger, C. M., Ghyselinck, N. B., and Noy, N. (2012a). Transthyretin blocks retinol uptake and cell signaling by the holo-retinol-binding protein receptor STRA6. Mol. Cell Biol. 32, 3851-3859. doi: 10.1128/MCB. 00775-12

Berry, D. C., Jacobs, H., Marwarha, G., Gely-Pernot, A., O’Byrne, S. M., DeSantis, D., et al. (2013). The STRA6 receptor is essential for retinol-binding proteininduced insulin resistance but not for maintaining vitamin A homeostasis in tissues other than the eye. J. Biol. Chem. 288, 24528-24539. doi: 10.1074/jbc. M113.484014

Berry, D. C., Jin, H., Majumdar, A., and Noy, N. (2011). Signaling by vitamin A and retinol-binding protein regulates gene expression to inhibit insulin responses. Proc. Natl. Acad. Sci. U.S.A. 1081, 4340-4345. doi: 10.1073/pnas. 1011115108

Berry, D. C., O’Byrne, S. M., Vreeland, A. C., Blaner, W. S., and Noy, N. (2012b). Cross talk between signaling and vitamin A transport by the retinol-binding protein receptor STRA6. Mol. Cell Biol. 32, 3164-3175. doi: 10.1128/MCB. 00505- 12

\section{AUTHOR CONTRIBUTIONS}

JSS and MS wrote the manuscript. AL gave intellectual input and edited the manuscript. All authors contributed to the article and approved the submitted version.

\section{FUNDING}

This work was supported by the German Research Foundation (DFG, SCHU 2546/4-1 and SCHU 2546/5-1) to MS and by the Austrian Science Fund (FWF, I3535) to AL. We acknowledge support from the DFG and the Open Access Publication Fund of Charité-Universitätsmedizin Berlin.

Bianconcini, A., Lupo, A., Capone, S., Quadro, L., Monti, M., Zurlo, D., et al. (2009). Transcriptional activity of the murine retinol-binding protein gene is regulated by a multiprotein complex containing HMGA1, p54 nrb/NonO, protein-associated splicing factor (PSF) and steroidogenic factor 1 (SF1)/liver receptor homologue 1 (LRH-1). Int. J. Biochem. Cell. Biol. 41, 2189-2203. doi: 10.1016/j.biocel.2009.04.011

Biesalski, H. K., Frank, J., Beck, S. C., Heinrich, F., Illek, B., Reifen, R., et al. (1999). Biochemical but not clinical vitamin A deficiency results from mutations in the gene for retinol binding protein. Am. J. Clin. Nutr. 69, 931-936. doi: 10.1093/ ajcn/69.5.931

Blaner, W. S. (1989). Retinol-binding protein: the serum transport protein for vitamin A. Endocr. Rev. 10, 308-316. doi: 10.1210/edrv-10-3-308

Blaner, W. S. (2007). STRA6, a cell-surface receptor for retinol-binding protein: the plot thickens. Cell Metab. 5, 164-166. doi: 10.1016/j.cmet.2007.02.006

Blaner, W. S., Piantedosi, R., Sykes, A., and Vogel, S. (1999). "Retinoic acid synthesis and metabolism," in Retinoids: The Biochemical and Molecular Basis of Vitamin A and Retinoid Action, eds H. Nau and W. S. Blaner (Berlin: Springer), 117-149.

Blegvad, O. (1924). Xerophthalmia, keratomalacia and xerosis conjunctivae. Am. J. Ophthalmol. 7, 89-117. doi: 10.1016/S0002-9394(24)90780-X

Bonventre, J. V., Vaidya, V. S., Schmouder, R., Feig, P., and Dieterle, F. (2010). Next-generation biomarkers for detecting kidney toxicity. Nat. Biotechnol. 28, 436-440. doi: 10.1038/nbt0510-436

Bouillet, P., Sapin, V., Chazaud, C., Messaddeq, N., Decimo, D., Dolle, P., et al. (1997). Developmental expression pattern of Stra6, a retinoic acid-responsive gene encoding a new type of membrane protein. Mech. Dev. 63, 173-186. doi: 10.1016/S0925-4773(97)00039-7

Buxbaum, J. N., Roberts, A. J., Adame, A., and Masliah, E. (2014). Silencing of murine transthyretin and retinol binding protein genes has distinct and shared behavioral and neuropathologic effects. Neuroscience 275, 352-364. doi: 10. 1016/j.neuroscience.2014.06.019

Cehajic-Kapetanovic, J., Jasani, K. M., Shanks, M., Clouston, P., and MacLaren, R. E. (2020). A novel homozygous c.67C $>$ T variant in retinol binding protein 4 (RBP4) associated with retinitis pigmentosa and childhood acne vulgaris. Ophthalmic Genet. 41, 288-292. doi: 10.1080/13816810.2020.1755985

Chassaing, N., Golzio, C., Odent, S., Lequeux, L., Vigouroux, A., MartinovicBouriel, J., et al. (2009). Phenotypic spectrum of STRA6 mutations: from Matthew-Wood syndrome to non-lethal anophthalmia. Hum. Mutat. 30, E673E681. doi: 10.1002/humu.21023

Chen, Y., Clarke, O. B., Kim, J., Stowe, S., Kim, Y. K., Assur, Z., et al. (2016). Structure of the STRA6 receptor for retinol uptake. Science 353:aad8266. doi: 10.1126/science.aad8266

Chiefari, E., Paonessa, F., Iiritano, S., Le Pera, I., Palmieri, D., Brunetti, G., et al. (2009). The cAMP-HMGA1-RBP4 system: a novel biochemical pathway for modulating glucose homeostasis. BMC Biol. 7:24. doi: 10.1186/1741-7007-7-24

Chou, C. M., Nelson, C., Tarle, S. A., Pribila, J. T., Bardakjian, T., Woods, S., et al. (2015). Biochemical basis for dominant inheritance, variable penetrance, and maternal effects in RBP4 congenital eye disease. Cell 161, 634-646. doi: 10.1016/j.cell.2015.03.006 
Christensen, E. I., Moskaug, J. O., Vorum, H., Jacobsen, C., Gundersen, T. E., Nykjaer, A., et al. (1999). Evidence for an essential role of megalin in transepithelial transport of retinol. J. Am. Soc. Nephrol. 10, 685-695.

Cioffi, C. L., Dobri, N., Freeman, E. E., Conlon, M. P., Chen, P., Stafford, D. G., et al. (2014). Design, synthesis, and evaluation of nonretinoid retinol binding protein 4 antagonists for the potential treatment of atrophic age-related macular degeneration and Stargardt disease. J. Med. Chem. 57, 7731-7757. doi: 10.1021/ jm5010013

Cioffi, C. L., Racz, B., Varadi, A., Freeman, E., Conlon, M. P., Chen, P., et al. (2019). Design, synthesis, and pre-clinical efficacy of novel non-retinoid antagonists of retinol binding protein 4 in the mouse model of hepatic steatosis. J. Med. Chem. 62, 5470-5500. doi: 10.1021/acs.jmedchem.9b00352

Codoñer-Franch, P., Carrasco-Luna, J., Allepuz, P., Codoñer-Alejos, A., and Guillem, V. (2016). Association of RBP4 genetic variants with childhood obesity and cardiovascular risk factors. Pediatr. Diabetes 17, 576-583. doi: 10.1111/pedi. 12339

Colantuoni, V., Pirozzi, A., Blance, C., and Cortese, R. (1987). Negative control of liver-specific gene expression: cloned human retinol-binding protein gene is repressed in HeLa cells. Embo J. 6, 631-636. doi: 10.1002/j.1460-2075.1987. tb04801.x

Craig, R. L., Chu, W. S., and Elbein, S. C. (2007). Retinol binding protein 4 as a candidate gene for type 2 diabetes and prediabetic intermediate traits. Mol. Genet. Metab. 90, 338-344. doi: 10.1016/j.ymgme.2006.11.003

Cukras, C., Gaasterland, T., Lee, P., Gudiseva, H. V., Chavali, V. R., Pullakhandam, R., et al. (2012). Exome analysis identified a novel mutation in the RBP4 gene in a consanguineous pedigree with retinal dystrophy and developmental abnormalities. PLoS One 7:e50205. doi: 10.1371/journal.pone.0050205

Decensi, A., Torrisi, R., Polizzi, A., Gesi, R., Brezzo, V., Rolando, M., et al. (1994). Effect of the synthetic retinoid fenretinide on dark adaptation and the ocular surface. J. Natl. Cancer Inst. 86, 105-110. doi: 10.1093/jnci/86.2.105

Dixon, J. L., and Goodman, D. S. (1987). Studies on the metabolism of retinolbinding protein by primary hepatocytes from retinol-deficient rats. J. Cell Physiol. 130, 14-20. doi: 10.1002/jcp.1041300104

Dobri, N., Qin, Q., Kong, J., Yamamoto, K., Liu, Z., Moiseyev, G., et al. (2013). A1120, a nonretinoid RBP4 antagonist, inhibits formation of cytotoxic bisretinoids in the animal model of enhanced retinal lipofuscinogenesis. Invest. Ophthalmol. Vis. Sci. 54, 85-95. doi: 10.1167/iovs.12-10050

D’Onofrio, C., Colantuoni, V., and Cortese, R. (1985). Structure and cell-specific expression of a cloned human retinol binding protein gene: the 5'-flanking region contains hepatoma specific transcriptional signals. Embo J. 4, 1981-1989. doi: 10.1002/j.1460-2075.1985.tb03881.x

Du, M., Otalora, L., Martin, A. A., Moiseyev, G., Vanlandingham, P., Wang, Q., et al. (2015). Transgenic mice overexpressing serum retinol-binding protein develop progressive retinal degeneration through a retinoid-independent mechanism. Mol. Cell Biol. 35, 2771-2789. doi: 10.1128/MCB.00181-15

Du, M., Phelps, E., Balangue, M. J., Dockins, A., Moiseyev, G., Shin, Y., et al. (2017). Transgenic mice over-expressing RBP4 Have RBP4-dependent and light-independent retinal degeneration. Invest. Ophthalmol. Vis. Sci. 58, 43754383. doi: 10.1167/iovs.17-22107

Duan, W., and Schreiber, G. (1992). Expression of retinol-binding protein mRNA in mammalian choroid plexus. Comp. Biochem. Physiol. B 101, 399-406. doi: 10.1016/0305-0491(92)90019-n

Fedders, R., Muenzner, M., and Schupp, M. (2015). Retinol binding protein 4 and its membrane receptors: a metabolic perspective. Horm. Mol. Biol. Clin. Investig. 22, 27-37. doi: 10.1515/hmbci-2015-0013

Fedders, R., Muenzner, M., Weber, P., Sommerfeld, M., Knauer, M., Kedziora, S., et al. (2018). Liver-secreted RBP4 does not impair glucose homeostasis in mice. J. Biol. Chem. 293, 15269-15276. doi: 10.1074/jbc.RA118.004294

Fenzl, A., Kulterer, O. C., Spirk, K., Mitulovic, G., Marculescu, R., Bilban, M., et al. (2020). Intact vitamin A transport is critical for cold-mediated adipose tissue browning and thermogenesis. Mol. Metab. 42:101088. doi: 10.1016/j.molmet. 2020.101088

Folli, C., Viglione, S., Busconi, M., and Berni, R. (2005). Biochemical basis for retinol deficiency induced by the I41N and G75D mutations in human plasma retinol-binding protein. Biochem. Biophys. Res. Commun. 336, 1017-1022. doi: 10.1016/j.bbrc.2005.08.227

Formelli, F., Clerici, M., Campa, T., Di Mauro, M. G., Magni, A., Mascotti, G., et al. (1993). Five-year administration of fenretinide: pharmacokinetics and effects on plasma retinol concentrations. J. Clin. Oncol. 11, 2036-2042. doi: 10.1200/JCO.1993.11.10.2036

Frey, S. K., Nagl, B., Henze, A., Raila, J., Schlosser, B., Berg, T., et al. (2008). Isoforms of retinol binding protein 4 (RBP4) are increased in chronic diseases of the kidney but not of the liver. Lipids Health Dis. 7:29. doi: 10.1186/1476-511X7-29

Golzio, C., Martinovic-Bouriel, J., Thomas, S., Mougou-Zrelli, S., GrattaglianoBessieres, B., Bonniere, M., et al. (2007). Matthew-Wood syndrome is caused by truncating mutations in the retinol-binding protein receptor gene STRA6. Am. J. Hum. Genet. 80, 1179-1187. doi: 10.1086/518177

Goodman, D. W., Huang, H. S., and Shiratori, T. (1965). Tissue distribution and metabolism of newly absorbed vitamin a in the rat. J. Lipid Res. 6, 390-396. doi: 10.1016/S0022-2275(20)39309-3

Graham, T. E., Wason, C. J., Bluher, M., and Kahn, B. B. (2007). Shortcomings in methodology complicate measurements of serum retinol binding protein (RBP4) in insulin-resistant human subjects. Diabetologia 50, 814-823. doi: 10. 1007/s00125-006-0557-0

Graham, T. E., Yang, Q., Bluher, M., Hammarstedt, A., Ciaraldi, T. P., Henry, R. R., et al. (2006). Retinol-binding protein 4 and insulin resistance in lean, obese, and diabetic subjects. N. Engl. J. Med. 354, 2552-2563. doi: 10.1056/NEJMoa054862

Haemmerle, G., and Lass, A. (2019). Genetically modified mouse models to study hepatic neutral lipid mobilization. Biochim. Biophys. Acta Mol. Basis Dis. 1865, 879-894. doi: 10.1016/j.bbadis.2018.06.001

Henze, A., Frey, S. K., Raila, J., Tepel, M., Scholze, A., Pfeiffer, A. F., et al. (2008). Evidence that kidney function but not type 2 diabetes determines retinolbinding protein 4 serum levels. Diabetes 57, 3323-3326. doi: 10.2337/db080866

Heyman, R. A., Mangelsdorf, D. J., Dyck, J. A., Stein, R. B., Eichele, G., Evans, R. M., et al. (1992). 9-cis retinoic acid is a high affinity ligand for the retinoid X receptor. Cell 68, 397-406. doi: 10.1016/0092-8674(92)90479-V

Holven, K. B., Natarajan, V., Gundersen, T. E., Moskaug, J. O., Norum, K. R., and Blomhoff, R. (1997). Secretion of N-(4-hydroxyphenyl) retinamide-retinolbinding protein from liver parenchymal cells: evidence for reduced affinity of the complex for transthyretin. Int. J. Cancer 71, 654-659. doi: 10.1002/(sici) 1097-0215(19970516)71:4<654::aid-ijc23<3.0.co;2-a

Hu, S., Ma, S., Li, X., Tian, Z., Liang, H., Yan, J., et al. (2019). Relationships of SLC2A4, RBP4, PCK1, and PI3K gene polymorphisms with gestational diabetes mellitus in a Chinese population. Biomed. Res. Int. 2019:7398063. doi: 10.1155/ 2019/7398063

Huang, H. J., Nanao, M., Stout, T. J., and Rosen, J. (2010). Structure of the complex of RBP4 with linoleic acid. Protein Data Bank doi: 10.2210/pdb2wr6/pdb

Hussain, R. M., Ciulla, T. A., Berrocal, A. M., Gregori, N. Z., Flynn, H. W. Jr., and Lam, B. L. (2018). Stargardt macular dystrophy and evolving therapies. Expert Opin. Biol. Ther. 18, 1049-1059. doi: 10.1080/14712598.2018.151 3486

Ingbar, S. H. (1963). Observations concerning the binding of thyroid hormones by human serum prealbumin. J. Clin. Invest. 42, 143-160. doi: 10.1172/JCI104701

Isken, A., Golczak, M., Oberhauser, V., Hunzelmann, S., Driever, W., Imanishi, Y., et al. (2008). RBP4 disrupts vitamin A uptake homeostasis in a STRA6deficient animal model for Matthew-Wood syndrome. Cell Metab. 7, 258-268. doi: 10.1016/j.cmet.2008.01.009

Jaconi, S., Rose, K., Hughes, G. J., Saurat, J. H., and Siegenthaler, G. (1995). Characterization of two post-translationally processed forms of human serum retinol-binding protein: altered ratios in chronic renal failure. J. Lipid Res. 36, 1247-1253. doi: 10.1016/S0022-2275(20)41132-0

Jaconi, S., Saurat, J. H., and Siegenthaler, G. (1996). Analysis of normal and truncated holo- and apo-retinol-binding protein (RBP) in human serum: altered ratios in chronic renal failure. Eur. J. Endocrinol. 134, 576-582. doi: 10.1530/eje.0.1340576

Janke, J., Engeli, S., Boschmann, M., Adams, F., Bohnke, J., Luft, F. C., et al. (2006). Retinol-binding protein 4 in human obesity. Diabetes 55, 2805-2810. doi: $10.2337 / \mathrm{db} 06-0616$

Jessen, K. A., and Satre, M. A. (1998). Induction of mouse retinol binding protein gene expression by cyclic AMP in Hepa 1-6 cells. Arch. Biochem. Biophys. 357, 126-130. doi: 10.1006/abbi.1998.0821

Jessen, K. A., and Satre, M. A. (2000). Mouse retinol binding protein gene: cloning, expression and regulation by retinoic acid. Mol. Cell. Biochem. 211, 85-94. doi: 10.1023/a:1007136612749 
Kanai, M., Raz, A., and Goodman, D. S. (1968). Retinol-binding protein: the transport protein for vitamin A in human plasma. J. Clin. Invest. 47, 2025-2044. doi: 10.1172/jci105889

Kane, M. A., Folias, A. E., and Napoli, J. L. (2008). HPLC/UV quantitation of retinal, retinol, and retinyl esters in serum and tissues. Anal. Biochem. 378, 71-79. doi: 10.1016/j.ab.2008.03.038

Kawaguchi, R., Yu, J., Honda, J., Hu, J., Whitelegge, J., Ping, P., et al. (2007). A membrane receptor for retinol binding protein mediates cellular uptake of vitamin A. Science 315, 820-825. doi: 10.1126/science.1136244

Kawaguchi, R., Yu, J., Ter-Stepanian, M., Zhong, M., Cheng, G., Yuan, Q., et al. (2011). Receptor-mediated cellular uptake mechanism that couples to intracellular storage. ACS Chem. Biol. 6, 1041-1051. doi: 10.1021/cb200178w

Kawaguchi, R., Yu, J., Wiita, P., Honda, J., and Sun, H. (2008). An essential ligandbinding domain in the membrane receptor for retinol-binding protein revealed by large-scale mutagenesis and a human polymorphism. J. Biol. Chem. 283, 15160-15168. doi: 10.1074/jbc.M801060200

Kawaguchi, R., Zhong, M., Kassai, M., Ter-Stepanian, M., and Sun, H. (2012). STRA6-catalyzed vitamin A influx, efflux, and exchange. J. Membr. Biol. 245, 731-745. doi: 10.1007/s00232-012-9463-1

Kersten, S., Seydoux, J., Peters, J. M., Gonzalez, F. J., Desvergne, B., and Wahli, W. (1999). Peroxisome proliferator-activated receptor alpha mediates the adaptive response to fasting. J. Clin. Invest. 103, 1489-1498. doi: 10.1172/JCI6223

Khan, K. N., Carss, K., Raymond, F. L., Islam, F., Nihr, BioResource-Rare Diseases, C., et al. (2017). Vitamin A deficiency due to bi-allelic mutation of RBP4: there's more to it than meets the eye. Ophthalmic Genet. 38, 465-466. doi: 10.1080/13816810.2016.1227453

Kilicarslan, M., de Weijer, B. A., Simonyte Sjodin, K., Aryal, P., Ter Horst, K. W., Cakir, H., et al. (2020). RBP4 increases lipolysis in human adipocytes and is associated with increased lipolysis and hepatic insulin resistance in obese women. FASEB J. 34, 6099-6110. doi: 10.1096/fj.201901979RR

Klöting, N., Graham, T. E., Berndt, J., Kralisch, S., Kovacs, P., Wason, C. J., et al. (2007). Serum retinol-binding protein is more highly expressed in visceral than in subcutaneous adipose tissue and is a marker of intra-abdominal fat mass. Cell Metab. 6, 79-87. doi: 10.1016/j.cmet.2007.06.002

Kovacs, P., Geyer, M., Berndt, J., Kloting, N., Graham, T. E., Bottcher, Y., et al. (2007). Effects of genetic variation in the human retinol binding protein-4 gene (RBP4) on insulin resistance and fat depot-specific mRNA expression. Diabetes 56, 3095-3100. doi: 10.2337/db06-1647

Krasinski, S. D., Cohn, J. S., Russell, R. M., and Schaefer, E. J. (1990). Postprandial plasma vitamin A metabolism in humans: a reassessment of the use of plasma retinyl esters as markers for intestinally derived chylomicrons and their remnants. Metabolism 39, 357-365. doi: 10.1016/0026-0495(90)90249-c

Kraus, B. J., Sartoretto, J. L., Polak, P., Hosooka, T., Shiroto, T., Eskurza, I., et al. (2015). Novel role for retinol-binding protein 4 in the regulation of blood pressure. FASEB J. 29, 3133-3140. doi: 10.1096/fj.14-266064

Laursen, K. B., Kashyap, V., Scandura, J., and Gudas, L. J. (2015). An alternative retinoic acid-responsive Stra6 promoter regulated in response to retinol deficiency. J. Biol. Chem. 290, 4356-4366. doi: 10.1074/jbc.M114.613968

Lee, S. A., Yuen, J. J., Jiang, H., Kahn, B. B., and Blaner, W. S. (2016). Adipocytespecific over-expression of retinol-binding protein 4 (RBP4) causes hepatic steatosis in mice. Hepatology 64, 1534-1546. doi: 10.1002/hep.28659

Levin, A. A., Sturzenbecker, L. J., Kazmer, S., Bosakowski, T., Huselton, C., Allenby, G., et al. (1992). 9-cis retinoic acid stereoisomer binds and activates the nuclear receptor RXR alpha. Nature 355, 359-361. doi: 10.1038/355359a0

Li, X., Zhu, S., Song, G., Zhang, K., Gao, W., Huang, J., et al. (2019). Retinolbinding protein 4 is closely correlated to blood pressure level and E/A in untreated essential hypertension patients. Ann. Palliat. Med. 8, 645-650. doi: 10.21037/apm.2019.11.07

Li, Z. Z., Lu, X. Z., Liu, J. B., and Chen, L. (2010). Serum retinol-binding protein 4 levels in patients with diabetic retinopathy. J. Int. Med. Res. 38, 95-99. doi: $10.1177 / 147323001003800111$

Liu, L., and Gudas, L. J. (2005). Disruption of the lecithin: retinol acyltransferase gene makes mice more susceptible to vitamin A deficiency. J. Biol. Chem. 280, 40226-40234. doi: 10.1074/jbc.M509643200

Liu, L., Suzuki, T., Shen, J., Wakana, S., Araki, K., Yamamura, K. I., et al. (2017). Rescue of retinal morphology and function in a humanized mouse at the mouse retinol-binding protein locus. Lab. Invest. 97, 395-408. doi: 10.1038/labinvest. 2016.156
Lobo, G. P., Pauer, G., Lipschutz, J. H., and Hagstrom, S. A. (2018). The RetinolBinding Protein Receptor 2 (Rbpr2) is required for photoreceptor survival and visual function in the zebrafish. Adv. Exp. Med. Biol. 1074, 569-576. doi: 10.1007/978-3-319-75402-4_69

MacDonald, P. N., Bok, D., and Ong, D. E. (1990). Localization of cellular retinolbinding protein and retinol-binding protein in cells comprising the blood-brain barrier of rat and human. Proc. Natl. Acad. Sci. U.S.A. 87, 4265-4269. doi: 10.1073/pnas.87.11.4265

Majerczyk, M., Choreza, P., Bozentowicz-Wikarek, M., Brzozowska, A., Arabzada, H., Owczarek, A., et al. (2017). Increased plasma RBP4 concentration in older hypertensives is related to the decreased kidney function and the number of antihypertensive drugs-results from the PolSenior substudy. J. Am. Soc. Hypertens. 11, 71-80. doi: 10.1016/j.jash.2016.11.009

Malpeli, G., Folli, C., and Berni, R. (1996). Retinoid binding to retinol-binding protein and the interference with the interaction with transthyretin. Biochim. Biophys. Acta 1294, 48-54. doi: 10.1016/0167-4838(95)00264-2

Mark, M., Ghyselinck, N. B., and Chambon, P. (2009). Function of retinoic acid receptors during embryonic development. Nucl. Recept. Signal. 7:e002. doi: $10.1621 /$ nrs.07002

Mata, N. L., Lichter, J. B., Vogel, R., Han, Y., Bui, T. V., and Singerman, L. J. (2013). Investigation of oral fenretinide for treatment of geographic atrophy in age-related macular degeneration. Retina 33, 498-507. doi: 10.1097/IAE. 0b013e318265801d

McCollum, E. V., and Davis, M. (1913). The necessity of certain lipids during growth. J. Biol. Chem. 15, 167-175. doi: 10.1016/S0021-9258(18) 88553-2

McIlroy, G. D., Delibegovic, M., Owen, C., Stoney, P. N., Shearer, K. D., McCaffery, P. J., et al. (2013). Fenretinide treatment prevents diet-induced obesity in association with major alterations in retinoid homeostatic gene expression in adipose, liver, and hypothalamus. Diabetes 62, 825-836. doi: $10.2337 / \mathrm{db} 12$ 0458

Meisinger, C., Ruckert, I. M., Rathmann, W., Doring, A., Thorand, B., Huth, C., et al. (2011). Retinol-binding protein 4 is associated with prediabetes in adults from the general population: the cooperative health research in the region of augsburg (KORA) F4 Study. Diabetes Care 34, 1648-1650. doi: 10.2337/dc110118

Mercader, J., Granados, N., Bonet, M. L., and Palou, A. (2008). All-trans retinoic acid decreases murine adipose retinol binding protein 4 production. Cell. Physiol. Biochem. 22, 363-372. doi: 10.1159/000149815

Monaco, H. L., Rizzi, M., and Coda, A. (1995). Structure of a complex of two plasma proteins: transthyretin and retinol-binding protein. Science 268, 1039-1041. doi: 10.1126/science.7754382

Mondul, A. M., Yu, K., Wheeler, W., Zhang, H., Weinstein, S. J., Major, J. M., et al. (2011). Genome-wide association study of circulating retinol levels. Hum. Mol. Genet. 20, 4724-4731. doi: 10.1093/hmg/ddr387

Moraes-Vieira, P. M., Castoldi, A., Aryal, P., Wellenstein, K., Peroni, O. D., and Kahn, B. B. (2016). Antigen presentation and T-Cell activation are critical for RBP4-induced insulin resistance. Diabetes 65, 1317-1327. doi: 10.2337/db151696

Moraes-Vieira, P. M., Yore, M. M., Dwyer, P. M., Syed, I., Aryal, P., and Kahn, B. B. (2014). RBP4 activates antigen-presenting cells, leading to adipose tissue inflammation and systemic insulin resistance. Cell Metab. 19, 512-526. doi: 10.1016/j.cmet.2014.01.018

Moraes-Vieira, P. M., Yore, M. M., Sontheimer-Phelps, A., Castoldi, A., Norseen, J., Aryal, P., et al. (2020). Retinol binding protein 4 primes the NLRP3 inflammasome by signaling through Toll-like receptors 2 and 4. Proc. Natl. Acad. Sci. U.S.A. 117, 31309-31318. doi: 10.1073/pnas.2013877117

Morriss-Kay, G. M., and Sokolova, N. (1996). Embryonic development and pattern formation. FASEB J. 10, 961-968. doi: 10.1096/fasebj.10.9.8801178

Motani, A., Wang, Z., Conn, M., Siegler, K., Zhang, Y., Liu, Q., et al. (2009). Identification and characterization of a non-retinoid ligand for retinol-binding protein 4 which lowers serum retinol-binding protein 4 levels in vivo. J. Biol. Chem. 284, 7673-7680. doi: 10.1074/jbc.M809654200

Muenzner, M., Tuvia, N., Deutschmann, C., Witte, N., Tolkachov, A., Valai, A., et al. (2013). Retinol-binding protein 4 and its membrane receptor STRA6 control adipogenesis by regulating cellular retinoid homeostasis and retinoic acid receptor alpha activity. Mol. Cell Biol. 33, 4068-4082. doi: 10.1128/MCB. 00221-13 
Munkhtulga, L., Nagashima, S., Nakayama, K., Utsumi, N., Yanagisawa, Y., Gotoh, T., et al. (2010). Regulatory SNP in the RBP4 gene modified the expression in adipocytes and associated with BMI. Obesity 18, 1006-1014. doi: 10.1038/oby. 2009.358

Munkhtulga, L., Nakayama, K., Utsumi, N., Yanagisawa, Y., Gotoh, T., Omi, T., et al. (2007). Identification of a regulatory SNP in the retinol binding protein 4 gene associated with type 2 diabetes in Mongolia. Hum. Genet. 120, 879-888. doi: 10.1007/s00439-006-0264-4

Muoio, D. M., and Newgard, C. B. (2005). Metabolism: a is for adipokine. Nature 436, 337-338. doi: 10.1038/436337a

Nanao, M., Mercer, D., Nguyen, L., Buckley, D., and Stout, T. J. (2010). Crystal structure of Rbp4 bound to oleic acid. Protein Data Bank doi: 10.2210/ $\mathrm{pdb} 2 \mathrm{WQ} 9 / \mathrm{pdb}$

Napoli, J. L. (1996). Biochemical pathways of retinoid transport, metabolism, and signal transduction. Clin. Immunol. Immunopathol. 80(3 Pt 2), S52-S62. doi: 10.1006/clin.1996.0142

Nau, H. (2001). Teratogenicity of isotretinoin revisited: species variation and the role of all-trans-retinoic acid. J. Am. Acad. Dermatol. 45, S183-S187. doi: 10. $1067 / \mathrm{mjd} .2001 .113720$

Naylor, H. M., and Newcomer, M. E. (1999). The structure of human retinolbinding protein (RBP) with its carrier protein transthyretin reveals an interaction with the carboxy terminus of RBP. Biochemistry 38, 2647-2653. doi: 10.1021/bi982291i

Newcomer, M. E., Jones, T. A., Aqvist, J., Sundelin, J., Eriksson, U., Rask, L., et al. (1984). The three-dimensional structure of retinol-binding protein. Embo J. 3, 1451-1454. doi: 10.1002/j.1460-2075.1984.tb01995.x

Norseen, J., Hosooka, T., Hammarstedt, A., Yore, M. M., Kant, S., Aryal, P., et al. (2012). Retinol-binding protein 4 inhibits insulin signaling in adipocytes by inducing proinflammatory cytokines in macrophages through a c-Jun $\mathrm{N}$-terminal kinase- and toll-like receptor 4-dependent and retinol-independent mechanism. Mol. Cell. Biol. 32, 2010-2019. doi: 10.1128/MCB.06193-11

O'Byrne, S. M., and Blaner, W. S. (2013). Retinol and retinyl esters: biochemistry and physiology. J. Lipid Res. 54, 1731-1743. doi: 10.1194/jlr.R037648

O’Byrne, S. M., Wongsiriroj, N., Libien, J. M., Vogel, S., Goldberg, I. J., Baehr, W., et al. (2005). Retinoid absorption and storage is impaired in mice lacking lecithin: retinol acyltransferase (LRAT). J. Biol. Chem. 280, 35647-35657. doi: 10.1074/jbc.M507924200

Palczewski, K., Kumasaka, T., Hori, T., Behnke, C. A., Motoshima, H., Fox, B. A., et al. (2000). Crystal structure of rhodopsin: a G protein-coupled receptor. Science 289, 739-745. doi: 10.1126/science.289.5480.739

Pasutto, F., Sticht, H., Hammersen, G., Gillessen-Kaesbach, G., Fitzpatrick, D. R., Nürnberg, G., et al. (2007). Mutations in STRA6 cause a broad spectrum of malformations including anophthalmia, congenital heart defects, diaphragmatic hernia, alveolar capillary dysplasia, lung hypoplasia, and mental retardation. Am. J. Hum. Genet. 80, 550-560. doi: 10.1086/512203

Perduca, M., Nicolis, S., Mannucci, B., Galliano, M., and Monaco, H. L. (2018). Human plasma retinol-binding protein (RBP4) is also a fatty acid-binding protein. Biochim. Biophys. Acta 1863, 458-466. doi: 10.1016/j.bbalip.2018.01. 010

Pervaiz, S., and Brew, K. (1987). Homology and structure-function correlations between alpha 1-acid glycoprotein and serum retinol-binding protein and its relatives. FASEB J. 1, 209-214. doi: 10.1096/fasebj.1.3.3622999

Petkovich, M., Brand, N. J., Krust, A., and Chambon, P. (1987). A human retinoic acid receptor which belongs to the family of nuclear receptors. Nature 330, 444-450. doi: 10.1038/330444a0

Pirie, A. (1983). Vitamin A deficiency and child blindness in the developing world. Proc. Nutr. Soc. 42, 53-64. doi: 10.1079/pns19830007

Preitner, F., Mody, N., Graham, T. E., Peroni, O. D., and Kahn, B. B. (2009). Longterm Fenretinide treatment prevents high-fat diet-induced obesity, insulin resistance, and hepatic steatosis. Am. J. Physiol. Endocrinol. Metab. 297, E1420E1429. doi: 10.1152/ajpendo.00362.2009

Quadro, L., Blaner, W. S., Hamberger, L., Van Gelder, R. N., Vogel, S., Piantedosi, R., et al. (2002). Muscle expression of human retinol-binding protein (RBP). Suppression of the visual defect of RBP knockout mice. J. Biol. Chem. 277, 30191-30197. doi: 10.1074/jbc.M205046200

Quadro, L., Blaner, W. S., Salchow, D. J., Vogel, S., Piantedosi, R., Gouras, P., et al. (1999). Impaired retinal function and vitamin A availability in mice lacking retinol-binding protein. Embo J. 18, 4633-4644. doi: 10.1093/emboj/18.17.4633
Quadro, L., Hamberger, L., Gottesman, M. E., Colantuoni, V., Ramakrishnan, R., and Blaner, W. S. (2004). Transplacental delivery of retinoid: the role of retinolbinding protein and lipoprotein retinyl ester. Am. J. Physiol. Endocrinol. Metab. 286, E844-E851. doi: 10.1152/ajpendo.00556.2003

Quadro, L., Hamberger, L., Gottesman, M. E., Wang, F., Colantuoni, V., Blaner, W. S., et al. (2005). Pathways of vitamin A delivery to the embryo: insights from a new tunable model of embryonic vitamin A deficiency. Endocrinology 146, 4479-4490. doi: 10.1210/en.2005-0158

Radu, R. A., Han, Y., Bui, T. V., Nusinowitz, S., Bok, D., Lichter, J., et al. (2005). Reductions in serum vitamin A arrest accumulation of toxic retinal fluorophores: a potential therapy for treatment of lipofuscin-based retinal diseases. Invest. Ophthalmol. Vis. Sci. 46, 4393-4401. doi: 10.1167/iovs.05-0820

Raila, J., Henze, A., Spranger, J., Mohlig, M., Pfeiffer, A. F., and Schweigert, F. J. (2007). Microalbuminuria is a major determinant of elevated plasma retinolbinding protein 4 in type 2 diabetic patients. Kidney Int. 72, 505-511. doi: 10.1038/sj.ki.5002372

Raila, J., Willnow, T. E., and Schweigert, F. J. (2005). Megalin-mediated reuptake of retinol in the kidneys of mice is essential for vitamin A homeostasis. J. Nutr. 135, 2512-2516. doi: 10.1093/jn/135.11.2512

Rask, L., Anundi, H., Böhme, J., Eriksson, U., Fredriksson, A., Nilsson, S. F., et al. (1980). The retinol-binding protein. Scand. J. Clin. Lab. Invest. Suppl. 154, 45-61.

Rask, L., Anundi, H., Fohlman, J., and Peterson, P. A. (1987). The complete amino acid sequence of human serum retinol-binding protein. Ups. J. Med. Sci. 92, 115-146. doi: 10.3109/03009738709178685

Rühl, R., Krzyzosiak, A., Niewiadomska-Cimicka, A., Rochel, N., Szeles, L., Vaz, B., et al. (2015). 9-cis-13,14-Dihydroretinoic acid is an endogenous retinoid acting as RXR Ligand in Mice. PLoS Genet. 11:e1005213. doi: 10.1371/journal.pgen. 1005213

Ruiz, A., Mark, M., Jacobs, H., Klopfenstein, M., Hu, J., Lloyd, M., et al. (2012). Retinoid content, visual responses, and ocular morphology are compromised in the retinas of mice lacking the retinol-binding protein receptor, STRA6. Invest. Ophthalmol. Vis. Sci. 53, 3027-3039. doi: 10.1167/iovs.11-8476

Schaffer, E. M., Ritter, S. J., and Smith, J. E. (1993). N-(4-hydroxyphenyl)retinamide (fenretinide) induces retinol-binding protein secretion from liver and accumulation in the kidneys in rats. J. Nutr. 123, 1497-1503. doi: 10.1093/jn/ 123.9.1497

Schreiber, R., Diwoky, C., Schoiswohl, G., Feiler, U., Wongsiriroj, N., Abdellatif, M., et al. (2017). Cold-induced thermogenesis depends on ATGL-mediated lipolysis in cardiac muscle, but not brown adipose tissue. Cell Metab. 26, 753.e7-763.e7. doi: 10.1016/j.cmet.2017.09.004

Seeliger, M. W., Biesalski, H. K., Wissinger, B., Gollnick, H., Gielen, S., Frank, J., et al. (1999). Phenotype in retinol deficiency due to a hereditary defect in retinol binding protein synthesis. Invest. Ophthalmol. Vis. Sci. 40, 3-11.

Shea, J. L., Loredo-Osti, J. C., and Sun, G. (2010). Association of RBP4 gene variants and serum HDL cholesterol levels in the Newfoundland population. Obesity 18, 1393-1397. doi: 10.1038/oby.2009.398

Shen, J., Shi, D., Suzuki, T., Xia, Z., Zhang, H., Araki, K., et al. (2016). Severe ocular phenotypes in Rbp4-deficient mice in the C57BL/6 genetic background. Lab. Invest. 96, 680-691. doi: 10.1038/labinvest.2016.39

Shi, Y., Obert, E., Rahman, B., Rohrer, B., and Lobo, G. P. (2017). The Retinol Binding Protein Receptor 2 (Rbpr2) is required for photoreceptor outer segment morphogenesis and visual function in Zebrafish. Sci. Rep. 7:16207. doi: 10.1038/s41598-017-16498-9

Shirakami, Y., Lee, S. A., Clugston, R. D., and Blaner, W. S. (2012). Hepatic metabolism of retinoids and disease associations. Biochim. Biophys. Acta 1821, 124-136. doi: 10.1016/j.bbalip.2011.06.023

Smati, S., Régnier, M., Fougeray, T., Polizzi, A., Fougerat, A., Lasserre, F., et al. (2020). Regulation of hepatokine gene expression in response to fasting and feeding: influence of PPAR- $\alpha$ and insulin-dependent signalling in hepatocytes. Diabetes Metab. 46, 129-136. doi: 10.1016/j.diabet.2019.05.005

Smith, J. E., Muto, Y., and Goodman, D. S. (1975). Tissue distribution and subcellular localization of retinol-binding protein in normal and vitamin A-deficient rats. J. Lipid Res. 16, 318-323. doi: 10.1016/S0022-2275(20)36720-1 Solanki, A. K., Kondkar, A. A., Fogerty, J., Su, Y., Kim, S. H., Lipschutz, J. H., et al. (2020). A functional binding domain in the Rbpr2 receptor is required for vitamin a transport, ocular retinoid homeostasis, and photoreceptor cell survival in Zebrafish. Cells 9:1099. doi: 10.3390/cells9051099 
Solini, A., Santini, E., Madec, S., Rossi, C., and Muscelli, E. (2009). Retinol-binding protein-4 in women with untreated essential hypertension. Am. J. Hypertens. 22, 1001-1006. doi: 10.1038/ajh.2009.116

Soprano, D. R., and Blaner, W. S. (1994). "Plasma retinol-binding protein," in The Retinoids: Biology, Chemistry, and Medicine, eds M. B. Sporn, A. B. Roberts, and D. S. Goodman (New York, NY: Raven Press Ltd.).

Soprano, D. R., Smith, J. E., and Goodman, D. S. (1982). Effect of retinol status on retinol-binding protein biosynthesis rate and translatable messenger RNA level in rat liver. J. Biol. Chem. 257, 7693-7697. doi: 10.1016/S0021-9258(18)34 437-5

Soprano, D. R., Soprano, K. J., and Goodman, D. S. (1986). Retinol-binding protein messenger RNA levels in the liver and in extrahepatic tissues of the rat. J. Lipid Res. 27, 166-171. doi: 10.1016/S0022-2275(20)38843-X

Stralfors, P., and Belfrage, P. (1983). Phosphorylation of hormone-sensitive lipase by cyclic AMP-dependent protein kinase. J. Biol. Chem. 258, 15146-15152. doi: 10.1074/jbc.M608048200

Sun, Q., Kiernan, U. A., Shi, L., Phillips, D. A., Kahn, B. B., Hu, F. B., et al. (2013). Plasma retinol-binding protein 4 (RBP4) levels and risk of coronary heart disease: a prospective analysis among women in the nurses' health study. Circulation 127, 1938-1947. doi: 10.1161/circulationaha.113.002073

Tamori, Y., Sakaue, H., and Kasuga, M. (2006). RBP4, an unexpected adipokine. Nat. Med. 12, 30-31; discussion 31. doi: 10.1038/nm0106-30

Taneja, R., Bouillet, P., Boylan, J. F., Gaub, M. P., Roy, B., Gudas, L. J., et al. (1995). Reexpression of retinoic acid receptor (RAR) gamma or overexpression of RAR alpha or RAR beta in RAR gamma-null F9 cells reveals a partial functional redundancy between the three RAR types. Proc. Natl. Acad. Sci. U.S.A. 92, 7854-7858. doi: 10.1073/pnas.92.17.7854

Thompson, S. J., Sargsyan, A., Lee, S. A., Yuen, J. J., Cai, J., Smalling, R., et al. (2017). Hepatocytes are the principal source of circulating RBP4 in Mice. Diabetes 66, 58-63. doi: $10.2337 / \mathrm{db} 16-0286$

Tsutsumi, C., Okuno, M., Tannous, L., Piantedosi, R., Allan, M., Goodman, D. S., et al. (1992). Retinoids and retinoid-binding protein expression in rat adipocytes. J. Biol. Chem. 267, 1805-1810. doi: 10.1016/S0021-9258(18) 46017-6

Ulukaya, E., and Wood, E. J. (1999). Fenretinide and its relation to cancer. Cancer Treat. Rev. 25, 229-235. doi: 10.1053/ctrv.1999.0127

van Bennekum, A. M., Wei, S., Gamble, M. V., Vogel, S., Piantedosi, R., Gottesman, M., et al. (2001). Biochemical basis for depressed serum retinol levels in transthyretin-deficient mice. J. Biol. Chem. 276, 1107-1113. doi: 10.1074/jbc. M008091200

van Hoek, M., Dehghan, A., Zillikens, M. C., Hofman, A., Witteman, J. C., and Sijbrands, E. J. (2008). An RBP4 promoter polymorphism increases risk of type 2 diabetes. Diabetologia 51, 1423-1428. doi: 10.1007/s00125-008-1042-8

Vogel, S., Gamble, M. V., and Blaner, W. S. (1999). "Biosynthesis, absorption, metabolism and transport of retinoids", in Retinoids: The Biochemical and Molecular Basis of Vitamin A and Retinoid Action, eds H. Nau and W. S. Blaner (Berlin: Springer), 31-95.

Vogel, S., Piantedosi, R., O’Byrne, S. M., Kako, Y., Quadro, L., Gottesman, M. E., et al. (2002). Retinol-binding protein-deficient mice: biochemical basis for impaired vision. Biochemistry 41, 15360-15368. doi: 10.1021/bi0268551

von Lintig, J. (2012). Provitamin A metabolism and functions in mammalian biology. Am. J. Clin. Nutr. 96, 1234S-1244S. doi: 10.3945/ajcn.112.034629

von Lintig, J., Moon, J., Lee, J., and Ramkumar, S. (2020). Carotenoid metabolism at the intestinal barrier. Biochim. Biophys. Acta Mol. Cell Biol. Lipids 1865:158580. doi: 10.1016/j.bbalip.2019.158580

Wagner, C., Hois, V., Pajed, L., Pusch, L. M., Wolinski, H., Trauner, M., et al. (2020). Lysosomal acid lipase is the major acid retinyl ester hydrolase in cultured human hepatic stellate cells but not essential for retinyl ester degradation. Biochim. Biophys. Acta Mol. Cell Biol. Lipids 1865:158730. doi: 10.1016/j.bbalip.2020.158730
Wan, K., Zhao, J., Deng, Y., Chen, X., Zhang, Q., Zeng, Z., et al. (2014). A genetic polymorphism in RBP4 is associated with coronary artery disease. Int. J. Mol. Sci. 15, 22309-22319. doi: 10.3390/ijms151222309

Wei, S., Episkopou, V., Piantedosi, R., Maeda, S., Shimada, K., Gottesman, M. E., et al. (1995). Studies on the metabolism of retinol and retinol-binding protein in transthyretin-deficient mice produced by homologous recombination. J. Biol. Chem. 270, 866-870. doi: 10.1074/jbc.270.2.866

Wei, S., Lai, K., Patel, S., Piantedosi, R., Shen, H., Colantuoni, V., et al. (1997). Retinyl ester hydrolysis and retinol efflux from BFC-1beta adipocytes. J. Biol. Chem. 272, 14159-14165. doi: 10.1074/jbc.272.22.14159

Welles, J. E., Toro, A. L., Sunilkumar, S., Stevens, S. A., Purnell, C. J., Kimball, S. R., et al. (2020). Retinol binding protein 4 (Rbp4) mRNA translation in hepatocytes is enhanced by activation of mTORC1. Am. J. Physiol. Endocrinol. Metab. 320, E306-E315. doi: 10.1152/ajpendo.00494.2020

Wendler, C. C., Schmoldt, A., Flentke, G. R., Case, L. C., Quadro, L., Blaner, W. S., et al. (2003). Increased fibronectin deposition in embryonic hearts of retinol-binding protein-null mice. Circ. Res. 92, 920-928. doi: 10.1161/01.RES. $0000069030.30886 .8 \mathrm{~F}$

Wu, C., Macleod, I., and Su, A. I. (2013). BioGPS and MyGene.info: organizing online, gene-centric information. Nucleic Acids Res. 41, D561-D565. doi: 10. 1093/nar/gks1114

Wu, C., Orozco, C., Boyer, J., Leglise, M., Goodale, J., Batalov, S., et al. (2009). BioGPS: an extensible and customizable portal for querying and organizing gene annotation resources. Genome Biol. 10:R130. doi: 10.1186/gb-2009-10-11r130

Wu, Y., Li, H., Loos, R. J., Qi, Q., Hu, F. B., Liu, Y., et al. (2009). RBP4 variants are significantly associated with plasma RBP4 levels and hypertriglyceridemia risk in Chinese Hans. J. Lipid Res. 50, 1479-1486. doi: 10.1194/jlr.P900014JLR200

Yagmur, E., Weiskirchen, R., Gressner, A. M., Trautwein, C., and Tacke, F. (2007). Insulin resistance in liver cirrhosis is not associated with circulating retinolbinding protein 4. Diabetes Care 30, 1168-1172. doi: 10.2337/dc06-2323

Yamada, M., Blaner, W. S., Soprano, D. R., Dixon, J. L., Kjeldbye, H. M., and Goodman, D. S. (1987). Biochemical characteristics of isolated rat liver stellate cells. Hepatology 7, 1224-1229. doi: 10.1002/hep.1840070609

Yang, Q., Graham, T. E., Mody, N., Preitner, F., Peroni, O. D., Zabolotny, J. M., et al. (2005). Serum retinol binding protein 4 contributes to insulin resistance in obesity and type 2 diabetes. Nature 436, 356-362. doi: 10.1038/nature03711

Zajc, C. U., Dobersberger, M., Schaffner, I., Mlynek, G., Puhringer, D., Salzer, B., et al. (2020). A conformation-specific ON-switch for controlling CAR T cells with an orally available drug. Proc. Natl. Acad. Sci. U.S.A. 117, 14926-14935. doi: 10.1073/pnas.1911154117

Zhong, M., Kawaguchi, R., Costabile, B., Tang, Y., Hu, J., Cheng, G., et al. (2020). Regulatory mechanism for the transmembrane receptor that mediates bidirectional vitamin A transport. Proc. Natl. Acad. Sci. U.S.A. 117, 9857-9864. doi: 10.1073/pnas.1918540117

Zhong, M., Kawaguchi, R., Kassai, M., and Sun, H. (2014). How free retinol behaves differently from rbp-bound retinol in RBP receptor-mediated vitamin A uptake. Mol. Cell Biol. 34, 2108-2110. doi: 10.1128/MCB.01426-12

Conflict of Interest: The authors declare that the research was conducted in the absence of any commercial or financial relationships that could be construed as a potential conflict of interest.

Copyright (C) 2021 Steinhoff, Lass and Schupp. This is an open-access article distributed under the terms of the Creative Commons Attribution License (CC BY). The use, distribution or reproduction in other forums is permitted, provided the original author(s) and the copyright owner(s) are credited and that the original publication in this journal is cited, in accordance with accepted academic practice. No use, distribution or reproduction is permitted which does not comply with these terms. 